\title{
The Epac-Phospholipase C $\varepsilon$ Pathway Regulates Endocannabinoid Signaling and Cocaine-Induced Disinhibition of Ventral Tegmental Area Dopamine Neurons
}

\author{
미iaqing Tong, ${ }^{1}$ ○Xiaojie Liu, ${ }^{1}{ }^{\circledR C}$ Casey Vickstrom, ${ }^{1}$ Yan Li, ${ }^{1}$ Laikang Yu, ${ }^{1}$ Youming Lu,,${ }^{2,3}$ Alan V. Smrcka, ${ }^{4}$ \\ and $₫$ Qing-Song Liu ${ }^{1}$ \\ ${ }^{1}$ Department of Pharmacology and Toxicology, Medical College of Wisconsin, Milwaukee, Wisconsin 53226, ${ }^{2}$ Neuroscience Center of Excellence and \\ Department of Neurology, Louisiana State University School of Medicine, New Orleans, Louisiana 70112, ${ }^{3}$ Department of Physiology, Tongji Medical \\ College and Institute for Brain Research, Huazhong University of Science and Technology, Wuhan 430030, China, and ${ }^{4}$ Department of Pharmacology, \\ University of Michigan Medical School, Ann Arbor, Michigan 48109
}

Exchange protein directly activated by cAMP (Epac) is a direct effector for the ubiquitous second messenger cAMP. Epac activates the phospholipase $C \varepsilon$ (PLC $\varepsilon$ ) pathway. PLC $\beta$ has been linked to the synthesis of the endocannabinoid 2-arachidonoylglycerol (2-AG). Here, we report that Epac facilitates endocannabinoid-mediated retrograde synaptic depression through activation of PLC $\varepsilon$. Intracellular loading of a selective Epac agonist 8-CPT-2Me-cAMP into ventral tegmental area (VTA) dopamine neurons enabled previously ineffective stimuli to induce depolarization-induced suppression of inhibition (DSI) and long-term depression of IPSCs (I-LTD) in the VTA. DSI and I-LTD are mediated by 2-AG since they were blocked by a diacylglycerol lipase inhibitor. The effects of 8-CPT-2Me-cAMP on DSI and I-LTD were absent in Epac2 and PLC $\varepsilon$ knock-out mice, but remained intact in Epac1 knock-out mice. These results identify a novel mechanism for on-demand synthesis of retrograde signaling 2-AG by the Epac2-PLC $\varepsilon$ pathway. We investigated the functional significance of Epac2-PLC $\varepsilon$-2-AG signaling in regulating inhibitory synaptic plasticity in VTA dopamine neurons induced by in vivo cocaine exposure. We showed that cocaine place conditioning led to a decrease in the frequency and amplitude of spontaneous IPSCs and an increase in action potential firing in wild-type mice, but not in Epac2 or PLC $\varepsilon$ knock-out mice. Together, these results indicate that the Epac2-PLC $\varepsilon-2-A G$ signaling cascade contributes to cocaine-induced disinhibition of VTA dopamine neurons.

Key words: endocannabinoid 2-arachidonoylglycerol; Epac; GABAergic disinhibition; phospholipase Ce; retrograde synaptic depression

Significance Statement

2-arachidonoylglycerol (2-AG) is an endogenous cannabinoid that depresses synaptic transmission through stimulation of $\mathrm{CB}_{1}$ receptors. Among the six isoforms of phospholipase C (PLC; PLC $\beta$, PLC $\gamma, \operatorname{PLC} \delta$, PLC $\varepsilon$, PLC $\zeta$, PLC $\eta$ ), only PLC $\beta$ has been linked to 2-AG synthesis. Here we demonstrate that 8-CPT-2Me-cAMP, a selective agonist of the cAMP sensor protein Epac, enhances 2-AG-mediated synaptic depression in ventral tegmental area (VTA) dopamine neurons via activation of PLC $\varepsilon$. These results identify a novel mechanism for 2-AG synthesis via activation of the Epac-PLC $\varepsilon$ pathway. Furthermore, we show that cocaineinduced conditioned place preference and disinhibition of VTA dopamine neurons were impaired in mice lacking Epac or PLC $\varepsilon$. Thus, the Epac-PLC $\varepsilon$ signaling pathway contributes to cocaine-induced disinhibition of VTA dopamine neurons and formation of drug-associated memories.

\section{Introduction}

Exchange protein directly activated by cAMP (Epac) is a direct intracellular effector of cAMP (Kawasaki et al., 1998; de Rooij et al., 1998). Epac mediates diverse functions of cAMP by acting as a guanine nucleotide exchange factor for Rap, a Ras-like small GTPase (Cheng et al., 2008; Gloerich and Bos, 2010; Schmidt et
Received Sept. 3, 2016; revised Jan. 26, 2017; accepted Feb. 6, 2017.

Author contributions: J.T., X.L., C.V., and Q.-S.L. designed research; J.T., X.L., C.V., Y. Li, and L.Y. performed research; Y. Lu and A.V.S. contributed unpublished reagents/analytic tools; J.T., X.L., C.V., Y. Li, and L.Y. analyzed data; J.T., X.L., C.V., and Q.-S.L. wrote the paper.

This work was supported by National Institutes of Health Grants DA035217 and MH101146 (to Q.S.L.) and GM053536 (to A.V.S.). It was also partially funded through the Research and Education Initiative Fund, a component of the Advancing a Healthier Wisconsin endowment at the Medical College of Wisconsin. C.V. is a member of the
Medical Scientist Training Program at MCW, which is partially supported by a training grant from NIGMS T32-GM080202.

The authors declare no competing financial interests.

Correspondence should be addressed to Qing-Song Liu, Department of Pharmacology and Toxicology, Medical College of Wisconsin, 8701 Watertown Plank Road, Milwaukee, WI 53226. E-mail: qsliu@mcw.edu.

DOI:10.1523/JNEUROSCI.2810-16.2017

Copyright $\odot 2017$ the authors $\quad 0270-6474 / 17 / 373030-15 \$ 15.00 / 0$ 
al., 2013). Epac-Rap activates phospholipase C $\varepsilon$ (PLC $\varepsilon$; Oestreich et al., 2007), a PLC isoform expressed in the heart (Oestreich et al., 2007) and brain (Wu et al., 2003). The Epac-RapPLC $\varepsilon$ signaling pathway regulates intracellular $\mathrm{Ca}^{2+}$ release in cardiac myocytes and cardiac contractility (Smrcka et al., 2012), but its role in neuronal signaling remains unknown.

Stimulation of $\mathrm{G}_{\mathrm{q} / 11}$-coupled receptors, such as group-I mGluRs, leads to the activation of PLC $\beta$ (Hashimotodani et al., 2005), which hydrolyzes membrane phospholipid to produce a pair of second messengers, inositol 1,4,5-trisphosphate (IP3) and 1,2-diacylglycerol (DAG). DAG is subsequently converted into the endocannabinoid 2-arachidonoylglycerol (2-AG) by DAG lipase (DAGL; Di Marzo et al., 1998; Piomelli, 2003). The mGluR agonist (S)-3,5-dihydroxyphenylglycine (DHPG) induces endocannabinoid-mediated retrograde synaptic depression (Maejima et al., 2001; Varma et al., 2001; Hashimotodani et al., 2005) and enhances depolarization-induced suppression of inhibition (DSI; Varma et al., 2001; Edwards et al., 2006). Synaptic stimulation of mGluRs induces endocannabinoid-mediated long-term depression (LTD) at excitatory and inhibitory synapses (I-LTD; Gerdeman et al., 2002; Robbe et al., 2002; Chevaleyre and Castillo, 2003, 2004). There are at least six isoforms of PLC (PLC $\beta, \operatorname{PLC} \gamma, \operatorname{PLC} \delta, \operatorname{PLC} \varepsilon, \operatorname{PLC} \zeta, \operatorname{PLC} \eta$; Rhee and Bae, 1997; Hwang et al., 2005). Among them, only PLC $\beta$ has been linked to 2-AG production via mGluRs (Hashimotodani et al., 2005). Based on the finding that Epac activates PLC $\varepsilon$ (Oestreich et al., 2007), we hypothesized that Epac-PLC $\varepsilon$ activation enhances 2-AG-mediated retrograde synaptic depression. To test this possibility, we examined the effects of the selective Epac agonist 8-CPT-2Me-cAMP (8-CPT) on DSI and I-LTD in dopamine neurons in the ventral tegmental area (VTA), and the involvement of Epac and PLC $\varepsilon$ was determined by using Epac (Yang et al., 2012) and PLC $\varepsilon$ knock-out mice (Oestreich et al., 2007).

Two genes, Epac1 and Epac2, encode Epac proteins. Epac2 is abundantly expressed in the brain, whereas Epacl expression in the brain is very low (Kawasaki et al., 1998; de Rooij et al., 1998). Epac2 $^{-/-}$mice exhibit deficits in social interaction and communication, but normal working and reference memory (Srivastava et al., 2012). Epac1 and Epac2 may be functionally redundant, as only Epac double-knock-out mice $\left(\right.$ Epac $\left.^{-/-}\right)$exhibit deficits in spatial learning and memory (Yang et al., 2012). Hippocampal Epac signaling is required for memory retrieval (Ouyang et al., 2008; Ostroveanu et al., 2010). We have shown that cocaine conditioned place preference (CPP) was impaired in Epac2 ${ }^{-1-}$ mice but was not significantly altered in $\mathrm{Epacl}^{-/-}$mice (Liu et al., 2016). Thus, Epac may contribute to memory formation and/or retrieval by spatial and drug-associated cues. Additionally, Epac2 is required for the cocaine-induced insertion of surface GluA2lacking AMPA receptors (AMPARs) in VTA dopamine neurons (Liu et al., 2016). Epac also regulates presynaptic glutamate release (Gekel and Neher, 2008; Zhao et al., 2013; Fernandes et al., 2015), LTP induction (Gelinas et al., 2008; Yang et al., 2012), and AMPAR trafficking (Ster et al., 2009; Woolfrey et al., 2009; Liu et al., 2016). However, the extent to which Epac regulates inhibitory transmission and plasticity remains essentially unknown.

Repeated cocaine exposure in vivo reduces GABAergic inhibition to VTA dopamine neurons ex vivo (Liu et al., 2005; Bocklisch et al., 2013). Endocannabinoid-mediated I-LTD provides a putative mechanism for cocaine-induced reduction of GABAergic inhibition (Pan et al., 2008a). We examined whether Epac-PLC $\varepsilon$ is required for the reduction of GABAergic inhibition to VTA dopamine neurons induced by cocaine exposure in vivo. Our studies reveal a novel mechanism for Epac-PLC $\varepsilon$ in regulating endocannabinoid-mediated retrograde synaptic depression and cocaine-induced inhibitory synaptic plasticity in VTA dopamine neurons.

\section{Materials and Methods}

Animals. Animal maintenance and use were in accordance with protocols approved by the Institutional Animal Care and Use Committee of Medical College of Wisconsin. Epac1 knock-out mice $\left(\right.$ Epac1 $\left.^{-1-}\right)$, Epac2 knock-out mice $\left(\right.$ Epac2 $\left.^{-/-}\right)$, and Epac1 and Epac2 double-knock-out mice $\left(\mathrm{Epac}^{-1-}\right)$ were generated and maintained on a 129Sv background in the laboratory of Youming $\mathrm{Lu}$ as detailed previously (Yang et al., 2012). The Epac1 ${ }^{-/-}$or Epac2 ${ }^{-/-}$mice were bred to $129 \mathrm{~Sv}$ wild-type mice at Medical College of Wisconsin for $\geq 2$ generations to generate heterozygous Epac1 ${ }^{+/-}$or Epac2 ${ }^{+/-}$breeders. Wild-type $\left(\mathrm{Epac}^{+/+}\right)$, $E p a c 1^{-1-}$, or $E p a c 2^{-1-}$ mice were generated by heterozygous $\times$ heterozygous breeding and all experiments were performed in agematched littermates of either sex. Epac double knock-out $\left(\right.$ Epac $\left.^{-1-}\right)$ mice were generated by crossing Epac1 ${ }^{-/-}$with Epac2 ${ }^{-/-}$mice. $P L C \varepsilon^{-1-}$ mice were generated in the laboratory of Alan Smrcka and maintained on C57BL/6 background as described previously (Wang et al., 2005). Genotyping analysis was performed by using standard PCR technique on tail biopsies.

Brain-slice preparation. Epac1 $1^{-/-}, \mathrm{Epac}^{-/-}, \mathrm{Epac}^{-/-}$mice, their wild-type littermates, $P L C \varepsilon^{-/-}$mice, and wild-type mice (P20-P30) of either sex were used for slice electrophysiology. In experiments described in Figures 6 and 8, adult wild-type, Epac2 $2^{-/-}$, and $P L C \varepsilon^{-/-}$mice of either sex ( $8-9$ weeks old at the beginning of the experiments) underwent place conditioning and behavioral tests (see below, CPP). Slices were prepared $24 \mathrm{~h}$ following behavioral tests. Mice were anesthetized by isoflurane inhalation and decapitated. The brain was embedded in lowmelting-point agarose, and horizontal midbrain slices (200 $\mu \mathrm{m}$ thick) were cut using a vibrating slicer (Leica VT1200s), as described in our recent study (Chen et al., 2016). Slices were prepared in a choline-based solution containing the following (in $\mathrm{mm}$ ): 110 choline chloride, $2.5 \mathrm{KCl}$, $1.25 \mathrm{NaH}_{2} \mathrm{PO}_{4}, 0.5 \mathrm{CaCl}_{2}, 7 \mathrm{MgSO}_{4}, 26 \mathrm{NaHCO}_{3}, 25$ glucose, 11.6 sodium ascorbate, and 3.1 sodium pyruvate at room temperature. The slices were incubated at room temperature for 30-40 $\mathrm{min}$ in sucrosebased solution containing the following (in $\mathrm{mm}$ ): $78 \mathrm{NaCl}$, 68 sucrose, 26 $\mathrm{NaHCO}_{3}, 2.5 \mathrm{KCl}, 1.25 \mathrm{NaH}_{2} \mathrm{PO}_{4}, 2 \mathrm{CaCl}_{2}, 2 \mathrm{MgCl}_{2}$, and 25 glucose. Then, the slices were allowed to recover for $\geq 30 \mathrm{~min}$ in the artificial CSF (ACSF) containing the following (in $\mathrm{mM}$ ): $119 \mathrm{NaCl}, 2.5 \mathrm{KCl}, 2.5 \mathrm{CaCl}_{2}$, $1 \mathrm{MgCl}_{2}, 1.25 \mathrm{NaH}_{2} \mathrm{PO}_{4}, 26 \mathrm{NaHCO}_{3}$, and 10 glucose.

Slice electrophysiology. Whole-cell patch-clamp recordings were made using patch-clamp amplifiers (Multiclamp 700B) under infrareddifferential interference contrast microscopy. Data acquisition and analysis were performed using DigiData 1440A and 1550B digitizers and analysis software pClamp 10 (Molecular Devices). Signals were filtered at $2 \mathrm{kHz}$ and sampled at $10 \mathrm{kHz}$. Dopamine neurons in the VTA (medial to the medial terminal nucleus of the accessory optic tract) were identified by long duration $(>1.5 \mathrm{~ms})$ of spontaneous action potentials in cellattached configuration (Chieng et al., 2011) and the presence of large $\mathrm{I}_{\mathrm{h}}$ currents $(>100 \mathrm{pA})$, rhythmic firing at low frequency $(<5 \mathrm{~Hz})$, and prominent afterhyperpolarization in whole-cell mode (Johnson and North, 1992; Jones and Kauer, 1999; Liu et al., 2005; Melis et al., 2008, 2013a). Neurons were voltage-clamped at $-70 \mathrm{mV}$ unless stated otherwise. Glutamate receptor antagonists 6-cyano-7-nitroquinoxaline2,3-dione (CNQX; $20 \mu \mathrm{M}$ ) and D-2-amino-5-phosphonovaleric acid (DAP-5; $50 \mu \mathrm{M}$ ) were present in the ACSF throughout the experiments. For recording of IPSCs, electrical stimulation was delivered by a bipolar tungsten stimulation electrode (WPI) placed $\sim 150 \mu \mathrm{m}$ rostral to the recorded dopamine neuron. Glass pipettes $(3-5 \mathrm{M} \Omega$ ) were filled with an internal solution containing the following (in $\mathrm{mm}$ ): $90 \mathrm{~K}$-gluconate, 50 $\mathrm{KCl}, 10$ HEPES, 0.2 EGTA, $2 \mathrm{MgCl}_{2}, 4 \mathrm{Mg}$-ATP, $0.3 \mathrm{Na}_{2} \mathrm{GTP}$, and 10 $\mathrm{Na}_{2}$-phosphocreatine, $\mathrm{pH} 7.2$ with $\mathrm{KOH}$. Intracellular perfusion of 8-CPT via whole-cell pipette was performed based on published procedure (Lapointe and Szabo, 1987; Tang et al., 1992; Maathuis et al., 1997). Whole-cell recordings were performed with an Axopatch holder with suction and perfusion ports (catalog \#660015, A-M Systems). 8-CPT- 
containing internal solution $(300 \mu \mathrm{M})$ was exchanged into the tip of the pipette via quartz tubing (Polymicro Technologies) connected to a PE-10 tube. Series resistance (15-30 M $\Omega$ ) was monitored throughout all recordings, and data were discarded if the resistance changed by $>20 \%$. All recordings were performed at $32 \pm 1^{\circ} \mathrm{C}$ by using an automatic temperature controller (Warner Instruments).

In vivo electrophysiology. Mice were anesthetized with intraperitoneal injection of urethane $(1.5 \mathrm{mg} / \mathrm{kg})$. Mice were positioned in a stereotaxic frame (David Kopf Instruments) and their body temperature was maintained at $37^{\circ} \mathrm{C}$ using a heating pad. Craniotomies were performed to allow single-unit recordings of VTA dopamine neurons. The areas for electrode insertion were moisturized with saline. Single-unit recording electrodes were pulled from micropipettes (outer diameter, $1 \mathrm{~mm}$; inner diameter, $0.5 \mathrm{~mm}$ ) to a resistance of $10-15 \mathrm{M} \Omega$ when filled with $0.5 \mathrm{M}$ $\mathrm{NaCl}$ containing $1.5 \%$ neurobiotin. The electrode was lowered into the VTA [coordinates from bregma: anteroposterior -2.9 to $-3.3 \mathrm{~mm}$, mediolateral $0.6-1.1 \mathrm{~mm}$, dorsoventral -3.9 to $-4.5 \mathrm{~mm}$ ] by a micromanipulator. A reference electrode was placed in the subcutaneous tissue. Single-unit activity was acquired with Multiclamp 700B amplifier and DigiData 1440 A digitizer and analyzed by pClamp 10 (Molecular Devices). Signals were filtered at $2 \mathrm{kHz}$ and sampled at $10 \mathrm{kHz}$. The bandpass filter was set between 0.3 and $5 \mathrm{kHz}$ (Brischoux et al., 2009). Dopamine neurons were identified by a broad triphasic extracellular action potential with a width of $>2 \mathrm{~ms}$ and a relatively slow firing rate ( $<10 \mathrm{~Hz}$; Ungless et al., 2004). The burst firing is defined as the occurrence of two consecutive spikes in an interval of $<80 \mathrm{~ms}$ and the termination of two consecutive spikes with an interval of $>160 \mathrm{~ms}$ (Grace and Bunney, 1984; Bishop et al., 2010; Schiemann et al., 2012; Chen and Lodge, 2013). To confirm cell type and electrode placement, neurons were juxtacellularly labeled with neurobiotin via iontophoresis (Pinault, 1996; Bocklisch et al., 2013). Briefly, following electrophysiological recordings, positive current pulses ( $7 \mathrm{~s}$ on/off cycles) were applied through the recording electrode to the neuron for $10 \mathrm{~min}$. The neurobiotin was allowed to transport within the neuron for another $1-2 \mathrm{~h}$ before the animals were killed for immunofluorescence staining (Pinault, 1996; Bocklisch et al., 2013).

CPP. Cocaine CPP was based on published procedures (Vialou et al., 2012). Epac2 $2^{-/-}, P L C \varepsilon^{-/-}$, and wild-type control mice (8-9 weeks old) of either sex were placed into the middle chamber of the three-chamber conditioning apparatus (Med Associates) and allowed to explore three chambers freely for $20 \mathrm{~min}$. Time spent in every chamber was recorded. Mice showing unconditioned side preference ( $\geq 180 \mathrm{~s}$ disparity) were excluded. On the second and third days, mice were injected with saline $(0.9 \% \mathrm{NaCl}, 2 \mathrm{ml} / \mathrm{kg}$, i.p.) in the morning (between 8:00 and 10:00 A.M.) and confined to one chamber for $30 \mathrm{~min}$, and then the mice were injected with cocaine $(15 \mathrm{mg} / \mathrm{kg}$, i.p.) in the afternoon (between 3:00 and 5:00 P.M.) and confined for $30 \mathrm{~min}$ to the other chamber. On the fourth day, mice were tested for side preference without treatment for $20 \mathrm{~min}$ (between 12:00 and 2:00 P.M.).

Immunofluorescence staining. Following in vivo single-unit recording of VTA dopamine neurons, mice were perfused transcardially with $4 \%$ paraformaldehyde in $4 \%$ sucrose-PBS, pH 7.4. Coronal VTA sections ( 30 $\mu \mathrm{m})$ were cut with a Leica cryostat. VTA sections were first incubated with fluorescein streptavidin (1:200; Vector Laboratories) to retrieve the neurobiotin-labeled cell bodies. Then the selected tissue sections were incubated with primary antibody against tyrosine hydroxylase (TH; 1:300; Santa Cruz Biotechnology; 48 h) and anti-rabbit IgG Alexa Fluor 555 conjugate (1:500; Cell Signaling Technology) secondary antibody. Confocal imaging was performed using a Nikon TE2000-U inverted microscope equipped with the $\mathrm{C} 1 \mathrm{Plus}$ confocal system (laser light source for EGFP excitation, $488 \mathrm{~nm}$, C-FL B-2E/C FITC filter cube; laser light source for Texas Red excitation, $561 \mathrm{~nm}, \mathrm{C}-\mathrm{FL}$ Y-2E/C Texas filter cube). The images were acquired using a $10 \times$ CFI Plan $10 \times$ apochromat objective (numerical aperture, 0.45 ) or a CFI Plan Fluor $40 \times$ oil objective (numerical aperture, 1.4) Nikon D-Eclipse C1 camera and EZ-C1 software.

Chemicals. 8-CPT sodium salt, D-(-)-2-amino-5-phosphonopentanoic acid, DHPG, 6-Bnz-cAMP sodium salt, and H-89 dihydrochloride were obtained from Tocris Bioscience. 7,8-dihydroxyflavone, CNQX, and all other common chemicals were obtained from Sigma-Aldrich. DO34 and DO53 were kindly provided by Benjamin Cravatt at Scripps Research Institute. Cocaine $\mathrm{HCl}$ was kindly provided by the National Institute on Drug Abuse Drug Supply Program. Drugs were prepared as concentrated stock solutions and stored at -20 or $-80^{\circ} \mathrm{C}$ before use.

Statistics. Data are presented as the mean \pm SEM. The magnitude of DSI and I-LTD was calculated as we have described previously (Pan et al., 2008a, 2009). sIPSCs were analyzed using Mini-analysis (Synaptosft). CPP scores were calculated as the time spent in the cocaine-conditioned chamber minus that in saline-conditioned chamber (Zhong et al., 2012). In vivo dopamine neuron firing was analyzed using Clampfit 10.6. Datasets were compared with either Student's $t$ test or two-way ANOVA followed by Tukey's post hoc analysis. Results were considered significant at $p<0.05$.

\section{Results}

\section{Epac agonist 8-CPT facilitated DSI through activation of Epac2}

We investigated whether the selective Epac agonist 8-CPT altered DSI in midbrain slices prepared from wild-type $\left(\right.$ Epac $\left.^{+/+}\right)$and Epac1/2 (Epac $\left.{ }^{-/-}\right)$double-knock-out mice. Whole-cell voltageclamp recordings were made from VTA dopamine neurons with control internal solution or internal solution containing the selective Epac agonist 8-CPT (100 $\mu \mathrm{M})$. IPSCs were evoked by electrical stimulation of synaptic afferents at $4 \mathrm{~s}$ intervals in the presence of glutamate receptor antagonists CNQX $(20 \mu \mathrm{M})$ and D-AP-5 $(50 \mu \mathrm{M})$. We have shown that postsynaptic depolarization induced minimal or no DSI in VTA dopamine neurons in rats or wild-type mice (Pan et al., 2008a; Zhong et al., 2015). Consistent with these studies, we found that in wild-type slices, a brief depolarization of VTA dopamine neurons from -70 to 0 $\mathrm{mV}$ for $5 \mathrm{~s}$ did not induce significant depression of IPSCs with control internal solution $(7.3 \pm 4.0 \%, n=8)$ but induced DSI with internal solution containing 8 -CPT $(23.4 \pm 5.7 \%, n=9$; $t_{(15)}=2.4, p=0.031$ vs control; Fig. $\left.1 A\right)$. DSI induced with 8-CPT-containing internal solution was blocked by bath application of the $\mathrm{CB}_{1}$ receptor antagonist AM251 (2 $\mu \mathrm{M} ; 6.2 \pm 5.3 \%$, $n=7 ; t_{(14)}=2.3, p=0.040$ vs 8 -CPT; Fig. $\left.1 A\right)$. DSI was not induced in slices from Epac1 and Epac2 double-knock-out $\left(\mathrm{Epac}^{-1-}\right)$ mice with control or 8-CPT-containing internal solution (control, $4.2 \pm 4.3 \%, n=10$; 8 -CPT, $3.1 \pm 5.8 \%, n=8 ; t_{(16)}=$ 1.0, $p=0.323$; Fig. $1 B$ ).

Two genes, Epac1 and Epac2, encode Epac proteins (Kawasaki et al., 1998; de Rooij et al., 1998). We next determined whether Epac1 or Epac2 mediated the effects of 8 -CPT on DSI. In Epac1 $^{-/-}$slices, DSI was induced with 8-CPT-containing internal solution but not with 8 -CPT-free control internal solution (control, $3.7 \pm 3.9 \%, n=8$; 8 -CPT, $29.2 \pm 3.7 \%, n=8 ; t_{(14)}=$ 4.7, $p<0.001$; Fig. $1 C$ ). In Epac2 $2^{-\prime-}$ slices, DSI was not induced with either internal solution (control, $1.9 \pm 2.9 \%, n=8$; 8 -CPT, $4.8 \pm 2.6 \%, n=9 ; t_{(15)}=1.8, p=0.101$; Fig. $\left.1 D\right)$. Thus, Epac2, but not Epac1, mediates 8-CPT-induced facilitation of DSI in VTA dopamine neurons. Epacl is ubiquitously expressed in all tissues and its expression in the brain is low. Meanwhile, Epac2 is richly expressed in the brain (Kawasaki et al., 1998; de Rooij et al., 1998), which may explain the lack of effect of 8-CPT on DSI in Epac2 $^{-/-}$slices.

8-CPT is a cAMP analog that selectively activates Epac but not protein kinase A (PKA; Enserink et al., 2002), whereas 6-BnzcAMP is a cAMP analog that selectively activates PKA but does not affect Epac (Hewer et al., 2011). Nevertheless, they may have off-target effects at higher concentrations. As a control experiment, we examined whether 6-Bnz-cAMP altered DSI in VTA 

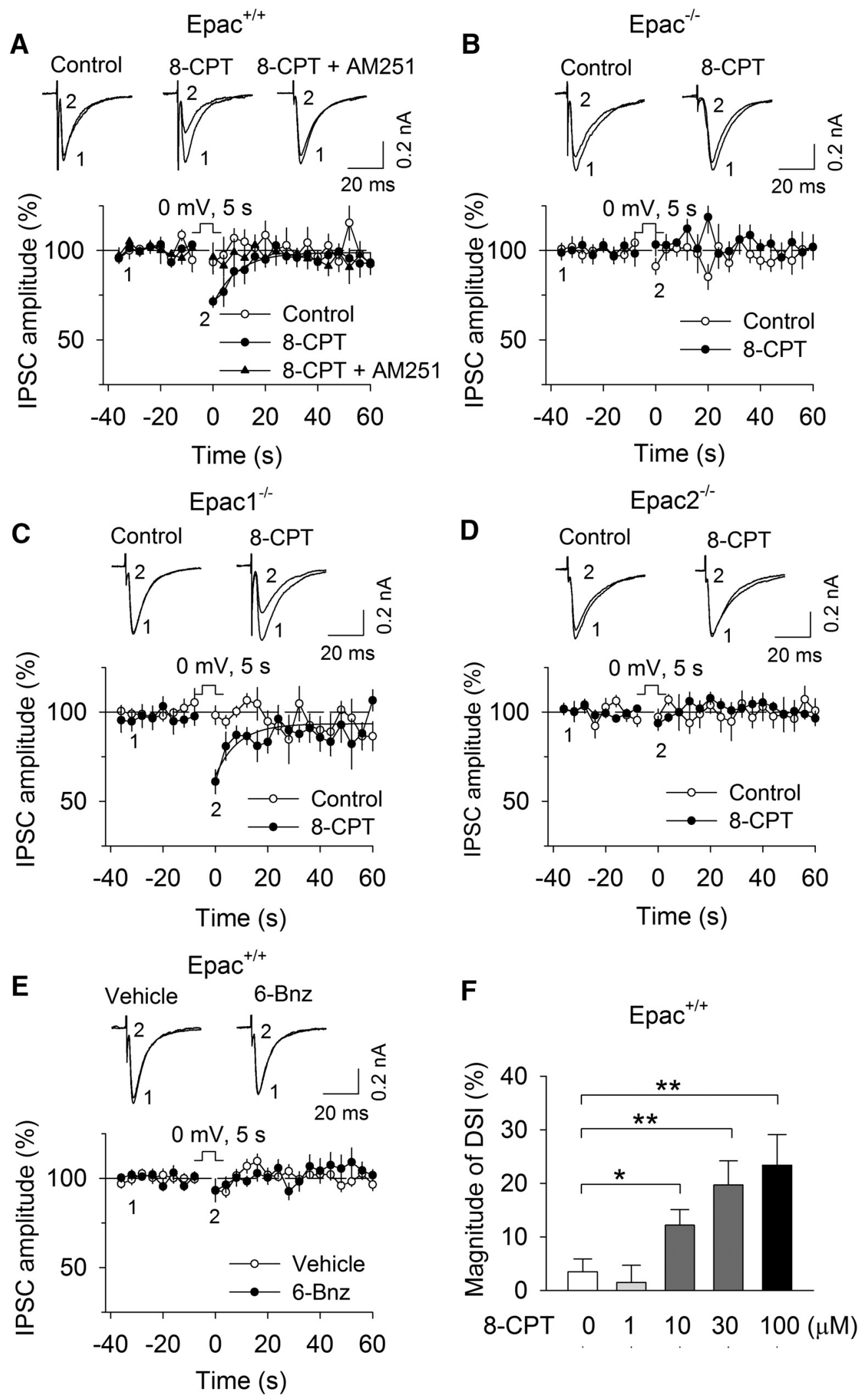

Figure 1. 8-CPT facilitated DSI by activating Epac2 in VTA dopamine neurons. $\boldsymbol{A}$, In Epac ${ }^{+/+}$slices, depolarization (from -70 to $0 \mathrm{mV}, 5 \mathrm{~s}$ ) did not induce DSI with control internal solution. Intracellular loading of 8-CPT (100 $\mu$ m) enabled DSI $(n=8-9, p=0.031)$. The 8-CPT-enabled DSI was blocked by the C $B_{1}$ receptor antagonist AM251 ( $\left.n=7, p=0.040\right)$. Sample traces of evoked IPSCs were shown on the top and averaged DSI on the bottom. The solid lines are single exponential fitting curves of the decay of DSI. $\boldsymbol{B}$, DSI was not induced in Epac ${ }^{-/-}$slices with control internal solution or 8-CPT-containing internal solution $(n=8-10, p=0.323)$. C, In Epac $1^{-1-}$ slices, 8-CPT enabled DSI (both $\left.n=8, p<0.001\right)$. D, DSI was not induced in Epac2 ${ }^{-1-}$ slices with control or 8-CPT-containing internal solution $(n=8-9, p=0.760)$. $\boldsymbol{E}$, DSI was not induced in Epac ${ }^{+/+}$slices with control or 6-Bnz-cAMP-containing internal solution ( $\left.n=8-9, p=0.101\right)$. $\boldsymbol{F}$, Dose-dependent effects of intracellular loading of different concentrations of 8-CPT $\left(n=7-10,{ }^{*} p<0.05,{ }^{* *} p<0.01\right)$. 

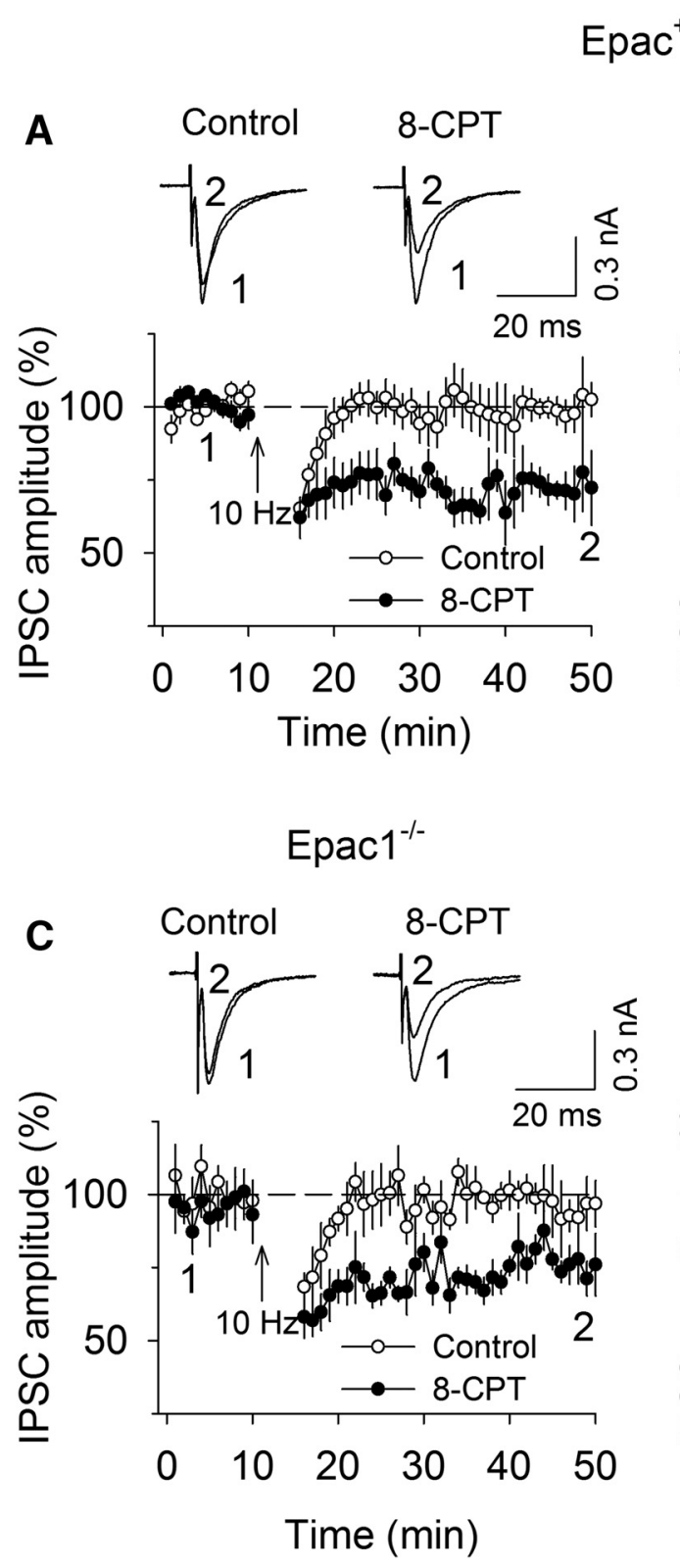

B

8-CPT + AM251
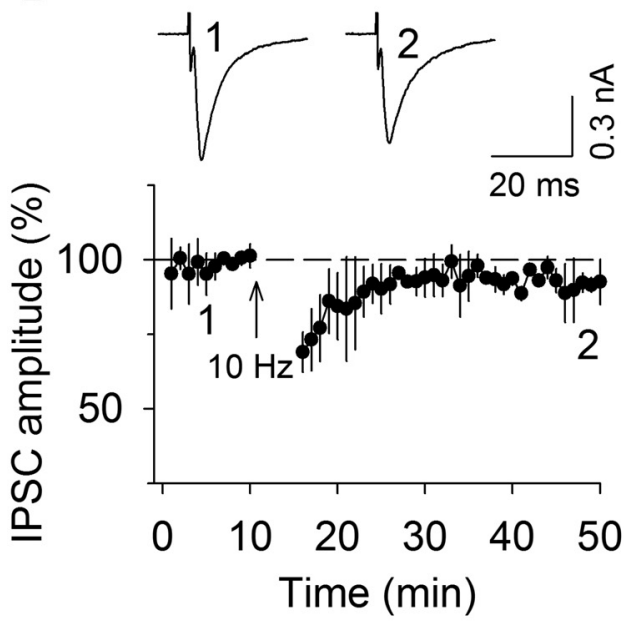

Epac2 $^{-/-}$

D
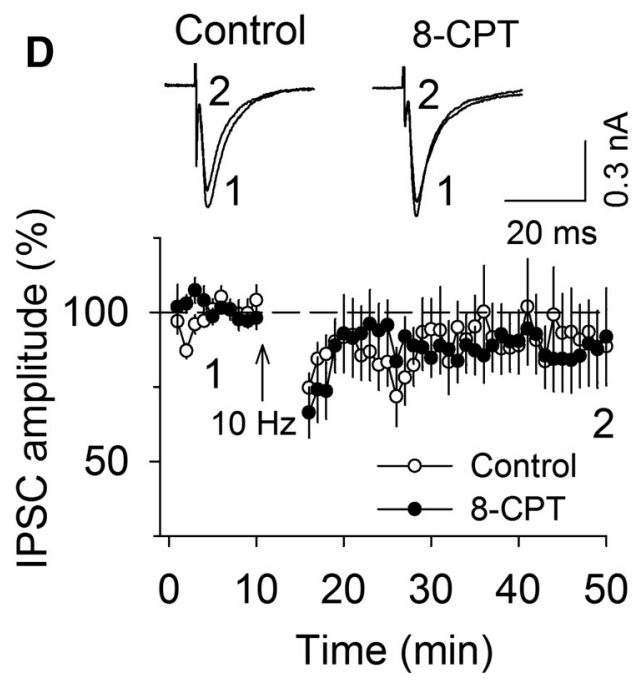

Figure 2. 8-CPT facilitated $\mathrm{CB}_{1}$ receptor-mediated I-LTD through the activation of Epac2. $A$, The $10 \mathrm{~Hz}, 5$ min stimulation (arrow) did not induce I-LTD with control internal solution ( $n=6, p=$ 0.914), while intracellular application of 8-CPT facilitated I-LTD $(n=8, p=0.022) . B, 8$-CPT-enabled I-LTD was blocked by AM251 $(n=6, p=0.355)$. C, In Epac ${ }^{-/-}$mice, I-LTD was not induced with control internal solution $(n=8, p=0.789)$, whereas 8-CPT enabled I-LTD $(n=9, p=0.030)$. D, I-LTD was not induced with control or 8-CPT-containing internal solution in Epac2 ${ }^{-/-}$slices $^{-}$ $(n=6-7, p>0.05)$.

dopamine neurons in $\mathrm{Epac}^{+/+}$slices. 6-Bnz-cAMP $(100 \mu \mathrm{M})$ was loaded into VTA dopamine neurons the same way as that of 8-CPT. However, 6-Bnz-cAMP did not enable DSI in VTA dopamine neurons $\left(5.3 \pm 4.9 \%, n=9 ; t_{(15)}=0.3\right.$ vs control, $p=0.760$; Fig. $1 E$ ). Thus, PKA is not required for 8 -CPT-induced facilitation of DSI in VTA dopamine neurons. We also examined whether intracellular loading of low concentrations of 8-CPT altered DSI in Epac ${ }^{+/+}$slices. We found that 8-CPT-induced facilitation of DSI was concentration-dependent at $1-100 \mu \mathrm{M}$ (control, $3.5 \pm 2.4 \%, n=8 ; 1 \mu \mathrm{M}, 1.5 \pm 3.2 \%, n=7, t_{(13)}=0.5$ vs control, $p=0.620 ; 10 \mu \mathrm{M}, 12.2 \pm 2.9 \%, n=10, t_{(16)}=2.2 \mathrm{vs}$ control, $p=0.040 ; 30 \mu \mathrm{M}, 19.7 \pm 4.5 \%, n=8 ; t_{(14)}=3.2 \mathrm{vs}$ control, $p=0.007 ; 100 \mu \mathrm{M}, 23.4 \pm 5.7 \%, n=9 ; t_{(15)}=3.1, p=$ 0.008 vs control; Fig. $1 F$ ).
8-CPT facilitated $\mathrm{CB}_{1}$ receptor-mediated I-LTD

The $\mathrm{CB}_{1}$ receptor not only mediates short-term synaptic depression, such as depolarization-induced suppression of excitation (DSE) and DSI (Kreitzer and Regehr, 2001; Ohno-Shosaku et al., 2001; Wilson and Nicoll, 2001), but also LTD and I-LTD (Gerdeman et al., 2002; Chevaleyre and Castillo, 2003; Safo and Regehr, 2005; Wang et al., 2010). We examined whether 8-CPT altered I-LTD induction in VTA dopamine neurons. Whole-cell recordings were made in wild-type slices with control internal solution or internal solution containing 8-CPT $(100 \mu \mathrm{M})$. After a stable baseline recording of IPSCs for $10 \mathrm{~min}$, repetitive synaptic stimulation $(10 \mathrm{~Hz}, 5 \mathrm{~min})$ was applied to induce I-LTD. Consistent with our previous studies (Pan et al., 2008a), we found that with control internal solution, the $10 \mathrm{~Hz}$ stimulation did not 
induce significant long-lasting depression of IPSCs (96.7 \pm $11.1 \%$ of baseline, $n=6 ; t_{(10)}=0.1, p=0.914$; Fig. $2 A$ ), suggesting that this stimulation is subthreshold for I-LTD induction. However, the $10 \mathrm{~Hz}$ stimulation for $5 \mathrm{~min}$ induced I-LTD when 8 -CPT was included in the internal solution $(72.5 \pm 10.0 \%$ of baseline, $n=8 ; t_{(14)}=2.6, p=0.022$; Fig. $\left.2 A\right)$. This I-LTD was blocked by the continuous presence of AM251 (2 $\mu \mathrm{M} ; 91.7 \pm$ $5.0 \%$ of baseline, $n=7 ; t_{(12)}=1.0, p=0.355$; Fig. $2 B$ ). These results indicate that 8 -CPT enabled a subthreshold stimulus to induce $\mathrm{CB}_{1}$ receptor-mediated I-LTD in VTA dopamine neurons.

We next examined whether 8-CPT altered I-LTD in VTA dopamine neurons in slices prepared from $\mathrm{Epac1}^{-/-}$and $E \mathrm{pac} 2^{-/-}$ mice. In Epac1 ${ }^{-/-}$slices, application of the $10 \mathrm{~Hz}$ stimulation for 5 min did not induce significant I-LTD with control internal solution $\left(96.8 \pm 8.1 \%\right.$ of baseline, $n=8 ; t_{(14)}=0.3, p=0.789$; Fig. 2C), while the same stimulation induced robust I-LTD with 8-CPT-containing internal solution $(74.9 \pm 7.1 \%$ of baseline, $n=9 ; t_{(16)}=2.4, p=0.030$; Fig. $\left.2 C\right)$. In Epac $2^{-1-}$ slices, the 10 $\mathrm{Hz}$ stimulation did not induce I-LTD when the recording pipette was filled with either control internal solution $(91.7 \pm 5.4 \%$ of baseline, $n=7 ; t_{(12)}=1.1, p=0.293$ ) or internal solution containing 8 -CPT $\left(93.0 \pm 3.6 \%\right.$ of baseline, $n=6 ; t_{(10)}=1.6, p=$ 0.145; Fig. 2D). Thus, 8 -CPT facilitates I-LTD through activation of Epac2 but not Epac1.

\section{Signaling mechanisms for 8-CPT-induced facilitation of DSI and I-LTD}

Epac is known to activate PLC $\varepsilon$ (Oestreich et al., 2007). PLC $\varepsilon$ has a conserved phosphoinositide-specific PLC (phosphoinositidase) catalytic core that hydrolyzes phosphatidylinositol 1,4,5bisphosphate $\left(\mathrm{PIP}_{2}\right)$ to $\mathrm{IP}_{3}$ and DAG (Smrcka et al., 2012). DAG is a precursor for the endocannabinoid 2-AG and is converted into 2-AG by DAGL (Di Marzo et al., 1998; Piomelli, 2003). One possibility is that 8-CPT enhances DSI and I-LTD via the PLC $\varepsilon \rightarrow$ $\mathrm{DAG} \rightarrow 2-\mathrm{AG}$ pathway. There are at least six isoforms of PLC (PLC $\beta, \mathrm{PLC} \gamma, \mathrm{PLC} \delta, \mathrm{PLC} \varepsilon, \mathrm{PLC} \zeta, \mathrm{PLC} \eta$; Rhee and Bae, 1997; Hwang et al., 2005). Currently available PLC inhibitors, such as U73122, cannot discriminate different PLC subtypes and have off-target effects (Walker et al., 1998; Hoover et al., 2008). We therefore tested whether 8-CPT altered DSI and I-LTD in VTA dopamine neurons in PLC $\varepsilon^{-/-}$mice (Wang et al., 2005). We found that DSI was induced in 8-CPT-filled VTA dopamine neurons in wild-type slices but not in $P L C \varepsilon^{-/-}$slices (wild type, $30.4 \pm 1.3 \%, n=8 ; P L C \varepsilon^{-/-}, 7.7 \pm 3.6 \%, n=9 ; t_{(15)}=5.7, p<$ 0.001 ; Fig. $3 A$ ). There is a possibility that genetic deletion of PLC $\varepsilon$ causes general deficits in 2-AG synthesis, which may account for the lack of effect of 8-CPT on DSI. We performed the following control experiments to test such a possibility.

Group-I mGluRs are coupled to the PLC $\beta$ pathway (Hashimotodani et al., 2005), while the tyrosine kinase receptor B (TrkB) is coupled to the PLC $\gamma$ pathway (Reichardt, 2006). The mGluR agonist DHPG and the TrkB agonist 7,8-dihydroxyflavone (DHF) enhance DSI (Varma et al., 2001; Edwards et al., 2006; Zhong et al., 2015) and induced $\mathrm{CB}_{1}$ receptor-dependent synaptic depression (Yu et al., 2013). We examined whether DHPGinduced and DHF-induced facilitation of DSI in VTA dopamine neurons was altered in $P L C \varepsilon^{-/-}$mice. In the presence of DHPG $(2 \mu \mathrm{M})$ in the ACSF, a brief depolarization $(-70$ to $0 \mathrm{mV}$ for $5 \mathrm{~s}$ ) induced DSI with comparable magnitude in wild-type and $P L C \varepsilon^{-/-}$slices (wild type, $30.0 \pm 7.6 \%, n=7 ; P L C \varepsilon^{-/-}, 29.9 \pm$ $2.1 \%, n=8 ; t_{(13)}=0.02, p=0.985$; Fig. $3 B$ ). Similarly, in the presence of DHF $(10 \mu \mathrm{M})$, there was no significant difference of
DSI in wild-type and PLC $\varepsilon^{-/-}$slices (wild type, 33.6 $\pm 5.1 \%, n=$ 9; PLC $\varepsilon^{-/-}, 30.8 \pm 7.3 \%, n=7 ; t_{(14)}=0.3, p=0.750$; Fig. $\left.3 C\right)$. Thus, genetic deletion of PLCE did not affect 2-AG synthesis through PLC $\beta$ and PLC $\gamma$ pathways. These results indicate that 8-CPT facilitated DSI in VTA dopamine neurons via activation of PLC $\varepsilon$.

We have shown earlier that 8-CPT enabled a subthreshold stimulus to induce I-LTD in VTA dopamine neurons (Fig. 2A). To determine whether PLC $\varepsilon$ mediates this effect of 8 -CPT, we examined I-LTD in slices prepared from wild-type and $P L C \varepsilon^{-/-}$ mice. Whole-cell recordings were made with internal solution containing 8-CPT $(100 \mu \mathrm{M})$. We found that the $10 \mathrm{~Hz}$ stimulation induced I-LTD in wild-type slices $(70.4 \pm 7.4 \%$ of baseline, $\left.n=6 ; t_{(10)}=3.3, p=0.009\right)$, but I-LTD was blocked in PLC $\varepsilon^{-/-}$ slices $\left(94.4 \pm 11.4 \%\right.$ of baseline, $n=6 ; t_{(10)}=0.4, p=0.697$; Fig. $3 D)$. Thus, the selective Epac agonist 8 -CPT facilitated I-LTD via activation of PLC $\varepsilon$.

As mentioned earlier, PLC $\varepsilon$ hydrolyzes $\mathrm{PIP}_{2}$ to DAG (Smrcka et al., 2012), and DAG is hydrolyzed into 2-AG by DAGL (Di Marzo et al., 1998; Piomelli, 2003). If the Epac agonist 8-CPT enabled DSI through activation of the PLC $\varepsilon \rightarrow$ DAG $\rightarrow 2-\mathrm{AG}$ pathway, then DAGL inhibitors should block 8-CPT-induced facilitation of DSI and I-LTD. To test this possibility, we examined the effects of DO34, a recently developed, highly selective and potent DAG lipase inhibitor (Ogasawara et al., 2016), on DSI and I-LTD in wild-type slices. DO53, an inactive analog of DO34, was used as a negative control (Ogasawara et al., 2016). Slices were pretreated with DO34 $(1 \mu \mathrm{M})$ or DO53 $(10 \mu \mathrm{M})$ for $30 \mathrm{~min}$ and these compounds were present in the ACSF throughout the experiments. 8-CPT was included in the internal solution used for whole-cell recordings. We found that DO53 did not significantly alter DSI ( $31.7 \pm 10.2 \%, n=8$; Fig. $4 A)$ and I-LTD (68.5 $\pm 9.5 \%$ of baseline, $n=6 ; t_{(10)}=3.2, p=0.010$; Fig. $\left.4 B\right)$, whereas DO34 blocked DSI $\left(2.4 \pm 2.6 \%, n=10 ; t_{(16)}=3.1, p=0.007\right.$; Fig. $\left.4 A\right)$ and I-LTD (90.4 $\pm 8.4 \%$ of baseline, $n=7 ; t_{(12)}=1.1, p=0.275$; Fig. $4 B$ ). These results suggest that 8 -CPT enabled I-LTD via the $\mathrm{PLC} \varepsilon \rightarrow \mathrm{DAG} \rightarrow 2-\mathrm{AG}$ pathway.

We examined whether intracellular perfusion of a higher concentration of 8-CPT ( $300 \mu \mathrm{M})$ via the patch pipette during wholecell recordings affected basal IPSCs in VTA dopamine neurons. Recordings were initially made with 8-CPT-free internal solution. After stable baseline recordings of IPSCs for $5 \mathrm{~min}, 8$-CPT was perfused to the tip of the patch pipette (see Materials and Methods). We found that 8-CPT perfusion caused gradual depression of IPSCs in $\mathrm{Epac}^{+/+}$slices $(72.3 \pm 6.8 \%$ of baseline, $n=$ $\left.7 ; t_{(12)}=3.0, p=0.011\right)$ but not in $E_{p a c 2^{-1-}}$ slices $(93.6 \pm 7.7 \%$ of baseline, $n=7 ; t_{(12)}=0.4, p=0.695$; Fig. $\left.5 A\right)$. 8-CPT-induced depression in $\mathrm{Epac}^{+/+}$slices was blocked by the DAGL inhibitor DO34 ( $1 \mu \mathrm{M} ; 96.8 \pm 8.2 \%$ of baseline, $n=6 ; t_{(11)}=2.3, p=0.043$ vs control; Fig. $5 B$ ) but was not significantly affected by the PKA inhibitor H89 $\left(70.4 \pm 6.3 \%\right.$ of baseline, $n=7 ; t_{(13)}=0.2, p=$ 0.809 vs control; Fig. $5 B$ ). In the latter experiment, slices were incubated $(\geq 1 \mathrm{~h})$ and continuously superfused with H89 (10 $\mu \mathrm{M})$. We and others have shown that under this condition H89 was effective in blocking PKA signaling (Chevaleyre et al., 2007; Pan et al., 2008b). Together, these results indicate that 8-CPT depresses basal IPSCs through the activation of the Epac $\rightarrow$ PLC $\varepsilon$ $\rightarrow \mathrm{DAG} \rightarrow 2$-AG pathway.

Epac2 is required for the reduction of GABAergic inhibition to dopamine neurons induced by cocaine CPP

We and others have shown that in vivo exposure to cocaine reduces GABAergic inhibition to VTA dopamine neurons in mid- 

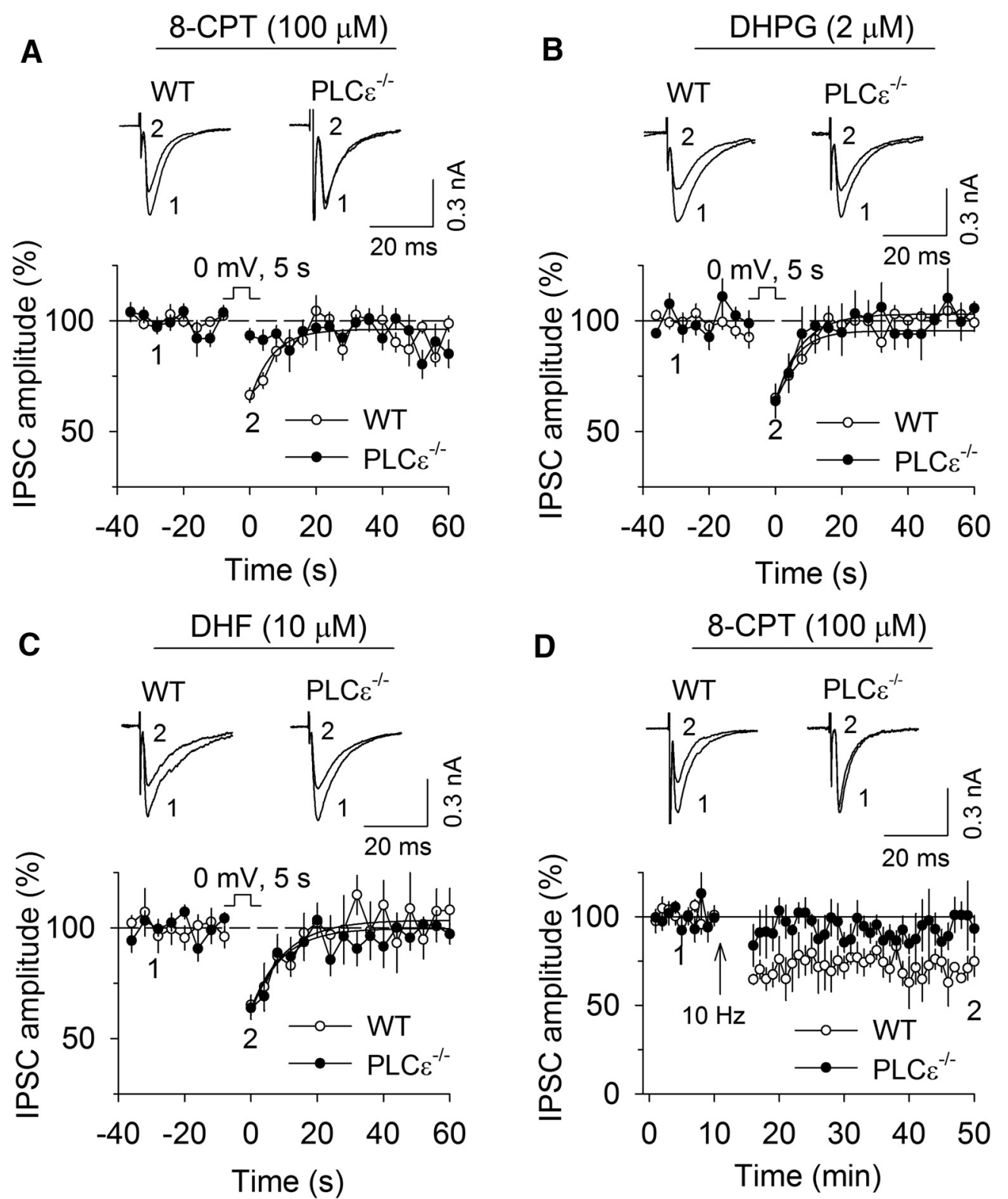

Figure 3. PLC $\varepsilon$ is required for 8-CPT-induced facilitation of DSI and I-LTD, but is not required for DHPG-induced or DHF-induced facilitation of DSI. $A$, 8-CPT enabled DSI in wild-type (WT) slices, but not in $P L\left(\varepsilon^{-/-}\right.$slices $(n=8-9, p<0.001)$. B, The mGluR1 agonist DHPG-enabled DSI was not altered in $P L C \varepsilon^{-/-}$slices $(n=7-8, p=0.985)$. C, TrkB agonist DHF-enabled DSI was not altered in PLC $\varepsilon^{-l-}$ slices $(n=7-9, p=0.750)$. D, 8-CPT enabled I-LTD in WT slices $(n=6, p=0.009)$. This I-LTD was absent in PLC $\varepsilon^{-/-}$slices $(n=6, p=0.697)$.

brain slices ex vivo (Liu et al., 2005; Bocklisch et al., 2013). Our previous studies suggest that the endocannabinoid-mediated I-LTD provides a putative mechanism for cocaine-induced reduction of GABAergic inhibition (Pan et al., 2008a). Having shown that Epac2 is required for I-LTD induction in VTA dopamine neurons, we next determined whether cocaine CPP altered spontaneous IPSCs (sIPSCs) in the VTA and, if so, whether the alteration was dependent on Epac2. Epac ${ }^{+/+}$and Epac2 ${ }^{-/-}$mice underwent saline and cocaine conditioning. Three mice that exhibited unconditioned place preference ( $\geq 180 \mathrm{~s}$ ) during the pretest were excluded from further experiments. The remaining mice did not exhibit baseline bias $(p>0.05$; Fig. $6 A)$. Then, cocaine $(15 \mathrm{mg} / \mathrm{kg}$, i.p.) or saline place conditioning was conducted twice daily for $2 \mathrm{~d}$. CPP was tested the next day without any drug or vehicle administration. Two-way ANOVA revealed that genotype $\left(F_{(1,36)}=12.8, p=0.001\right)$ and cocaine place conditioning $\left(F_{(1,36)}=64.1, p<0.001\right)$ had significant main effects on the preference score, and there was a significant interaction between genotype and cocaine conditioning $\left(F_{(1,36)}=9.7, p=\right.$ 0.004 ; Fig. $6 B$ ). Tukey's post hoc tests showed that cocaine conditioning led to a significant increase in the preference score $(p<0.001)$ in $\mathrm{Epac}^{+/+}$mice and that cocaine CPP was attenuated in Epac2 ${ }^{-/-}$mice $(p<0.001$; Fig. $6 B)$. These results are consistent with our recent studies showing that cocaine CPP is reduced in Epac2 ${ }^{-/-}$mice (Liu et al., 2016).

One day after the CPP test, the mice were killed and midbrain slices were prepared. Spontaneous IPSCs were recorded from VTA dopamine neurons in these four groups of mice. We found that cocaine treatment and genotype had significant effects on the mean amplitude of sIPSCs (cocaine: $F_{(1,47)}=5.9, p=0.019$; genotype: $F_{(1,47)}=5.9, p=0.020$; cocaine $\times$ genotype interaction: $F_{(1,47)}=15.8, p<0.001$; Fig. $\left.6 C, D\right)$ and the mean frequency of sIPSCs (cocaine: $F_{(1,47)}=4.5, p=0.040$; genotype: $F_{(1,47)}=$ 9.2, $p=0.004$; cocaine $\times$ genotype interaction: $F_{(1,47)}=9.5, p=$ 

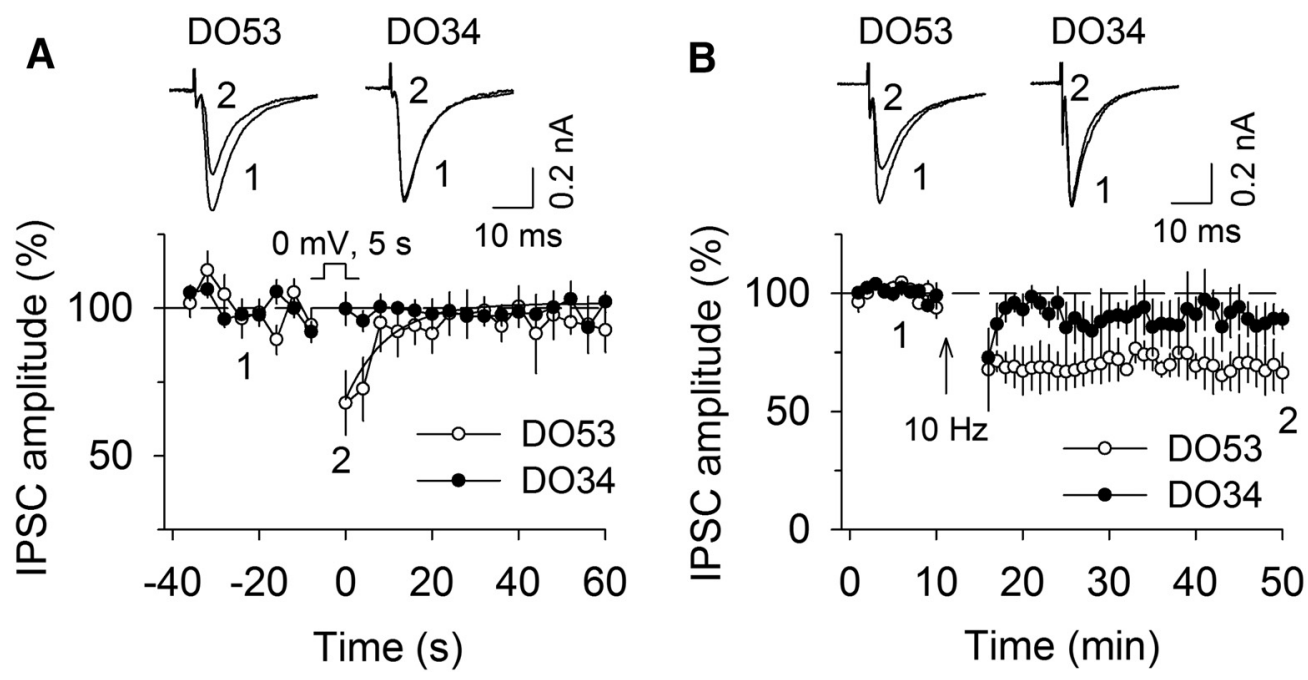

Figure 4. The DAGL inhibitor D034 blocked DSI and I-LTD in wild-type slices. $A, B$, DAGL inhibitor D034, but not the inactive analog D053, blocked 8-CPT-enabled DSI $(n=8-10, p=0.007$; A) and I-LTD $(n=6-7, p=0.010 ; B)$.
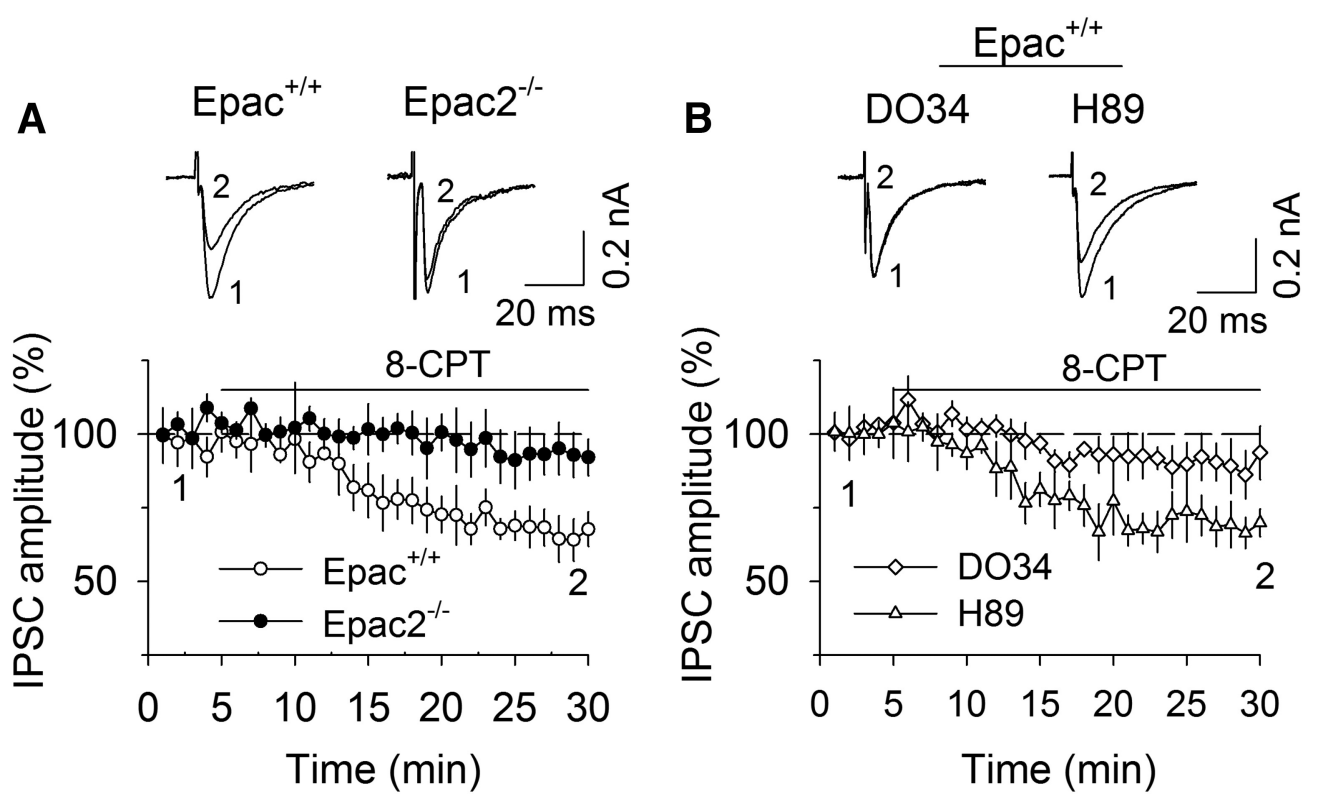

Figure 5. Intracellular perfusion of a higher concentration of 8-CPT (300 $\mu \mathrm{M})$ depressed basal IPSCs. A, 8-CPT depressed IPSCs in Epac ${ }^{+/+}$slices $(n=7, p=0.011)$ but not in Epac2 ${ }^{-/-}$slices $(n=7, p=0.695)$. B, 8-CPT-induced depression of IPSCs in the Epac ${ }^{+/+}$slices was blocked by the DAGL inhibitor D034 $(n=6-7, p=0.043)$ but was unaffected by the PKA inhibitor H89 ( $n=7-8, p=0.809)$.

0.004; Fig. 6C,E). Tukey's post hoc tests indicated that cocaine conditioning significantly decreased the mean amplitude $(p<$ 0.001 ; Fig. $6 D)$ and frequency of sIPSCs $(p<0.001$; Fig. $6 E)$ in $\mathrm{Epac}^{+/+}$mice. The cocaine-induced decreases in the amplitude and frequency of sIPSCs were absent in $\mathrm{Epac2}^{-1-}$ mice $(p<$ 0.001 ; Fig. $6 D, E$ ). The cumulative distribution for the amplitude of sIPSCs was shifted to the left (i.e., smaller value) in $\mathrm{Epac}^{+/+}$ mice that received cocaine conditioning, and this shift was blocked in Epac2 ${ }^{-\prime-}$ mice (Fig. $6 F$ ). The cumulative distribution for interevent intervals of sIPSCs was shifted to the right (i.e., longer interval and less frequent) in $\mathrm{Epac}^{+/+}$mice that received cocaine conditioning, and this shift was blocked in Epac2 ${ }^{-/-}$ mice (Fig. 6G). Together, these results indicate that cocaine CPP led to the decrease in sIPSC amplitude and frequency in $\mathrm{Epac}^{+/+}$ mice, and this decrease was blocked in Epac2 ${ }^{-/-}$mice.
Cocaine-induced reduction of GABAergic inhibition was attenuated in $P L C \varepsilon^{-/-}$mice

Having shown that Epac2 is required for the cocaine-induced decrease in sIPSCs in VTA dopamine neurons (Fig. 6), we next determined whether PLC $\varepsilon$ is involved in this process. We examined whether cocaine-induced reduction of GABAergic inhibition was altered in $P L C \varepsilon^{-/-}$mice. Wild-type and $P L C \varepsilon^{-/-}$mice underwent saline and cocaine conditioning as described above. CPP was tested the next day without any drug or vehicle administration. Two-way ANOVA revealed that genotype $\left(F_{(1,36)}=\right.$ $11.4, p=0.002)$ and cocaine place conditioning $\left(F_{(1,36)}=127.2\right.$, $p<0.001)$ had significant main effects on the preference score, and there was a significant interaction between genotype and cocaine conditioning $\left(F_{(1,36)}=7.6, p=0.009\right.$; Fig. $\left.7 B\right)$. Tukey's post hoc tests showed that cocaine conditioning led to a significant 
Saline and cocaine conditioning

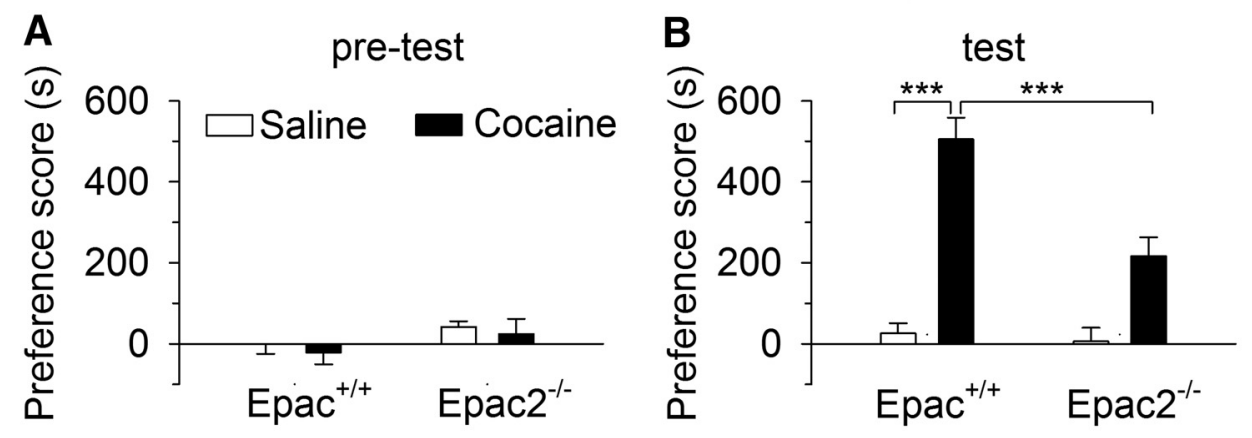

C $\quad \mathrm{Epac}^{+/+}$

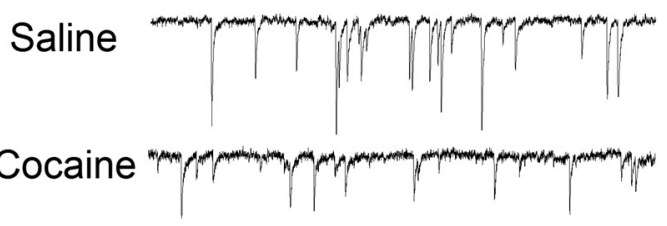

D

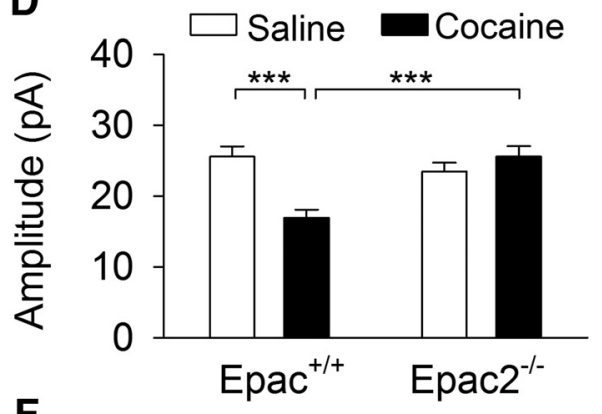

$\mathbf{F}$

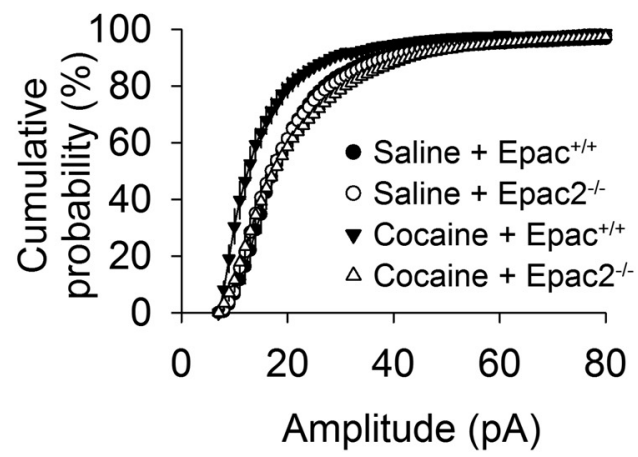

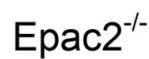
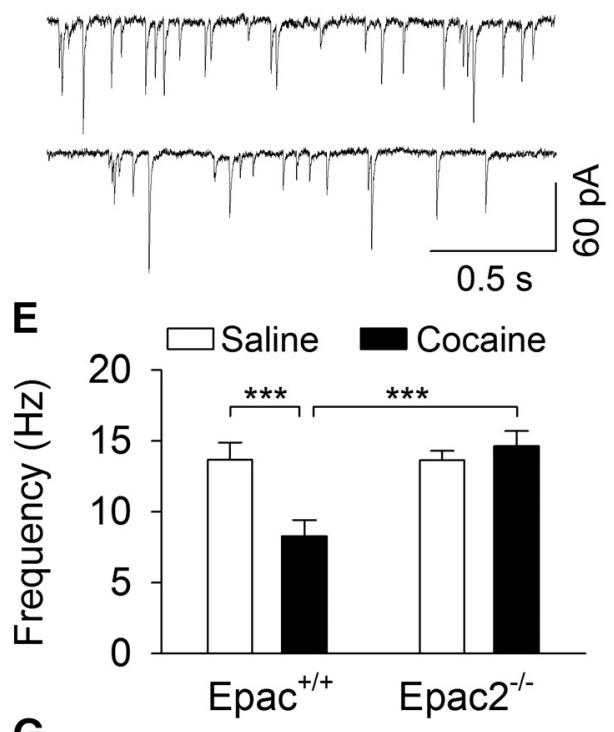

G

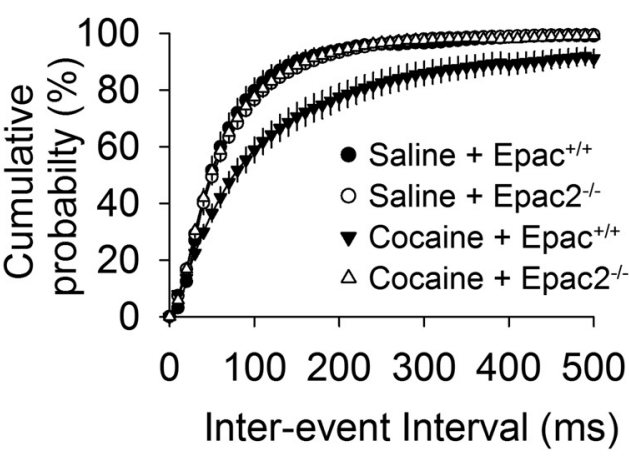

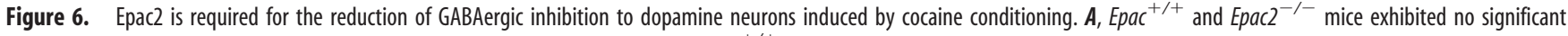
unconditioned preference in each chamber during pretest $(n=9-10, p>0.05) . \boldsymbol{B}$, In Epac ${ }^{+/+}$mice, cocaine conditioning induced a significant increase in preference score compared with saline conditioning $\left(n=9-10,{ }^{* *} p<0.001\right)$. Epac $2^{-/-}$mice exhibited a significant decrease in the preference score compared with that of Epac ${ }^{+/+}$mice $\left(n=9-10,{ }^{* *} p<0.001\right)$. C, Representative sIPSCs recorded from VTA dopamine neurons in slices prepared from saline-conditioned or cocaine-conditioned Epac ${ }^{+/+}$or Epac $2^{-/-}$mice. $\boldsymbol{D}, \boldsymbol{E}$, The averaged amplitude $(\boldsymbol{D})$ and frequency $(\boldsymbol{E})$ of sIPSCs in VTA dopamine neurons in these four groups of mice. The mean amplitude and frequency of sIPSCs were significantly decreased in cocaine-conditioned Epac ${ }^{+/+}$mice (both $n=12,{ }^{* *} p<0.001$ ), and this decrease was blocked in Epac2 ${ }^{-/-}$mice (both $\left.n=12,{ }^{* *} p<0.001\right) . F, G$, The cumulative probability plots indicated that cocaine conditioning led to shifts in the distribution of the amplitude $(\boldsymbol{F})$ and interevent intervals $(\boldsymbol{G})$ in Epac ${ }^{+/+}$mice. These shifts were blocked in Epac2 $2^{-/-}$mice $(n=12, p<0.01)$.

increase in the preference score $(p<0.001)$ in wild-type mice, and cocaine-induced CPP was attenuated in $P L C \varepsilon^{-/-}$mice $(p<$ 0.001; Fig. 7B).

One day after the CPP test, the mice were killed and midbrain slices were prepared. Spontaneous IPSCs were recorded from VTA dopamine neurons in these four groups of mice. We found that cocaine conditioning $\left(F_{(1,55)}=16.6, p<0.001\right)$ and genotype $\left(F_{(1,55)}=4.9, p=0.032\right)$ had significant effects on the mean amplitude of sIPSCs, and there was a significant interaction between cocaine conditioning and genotype $\left(F_{(1,55)}=27.9, p<\right.$ 0.001; Fig. 7C,D). Tukey's post hoc tests indicated that cocaine conditioning significantly decreased the mean amplitude of 

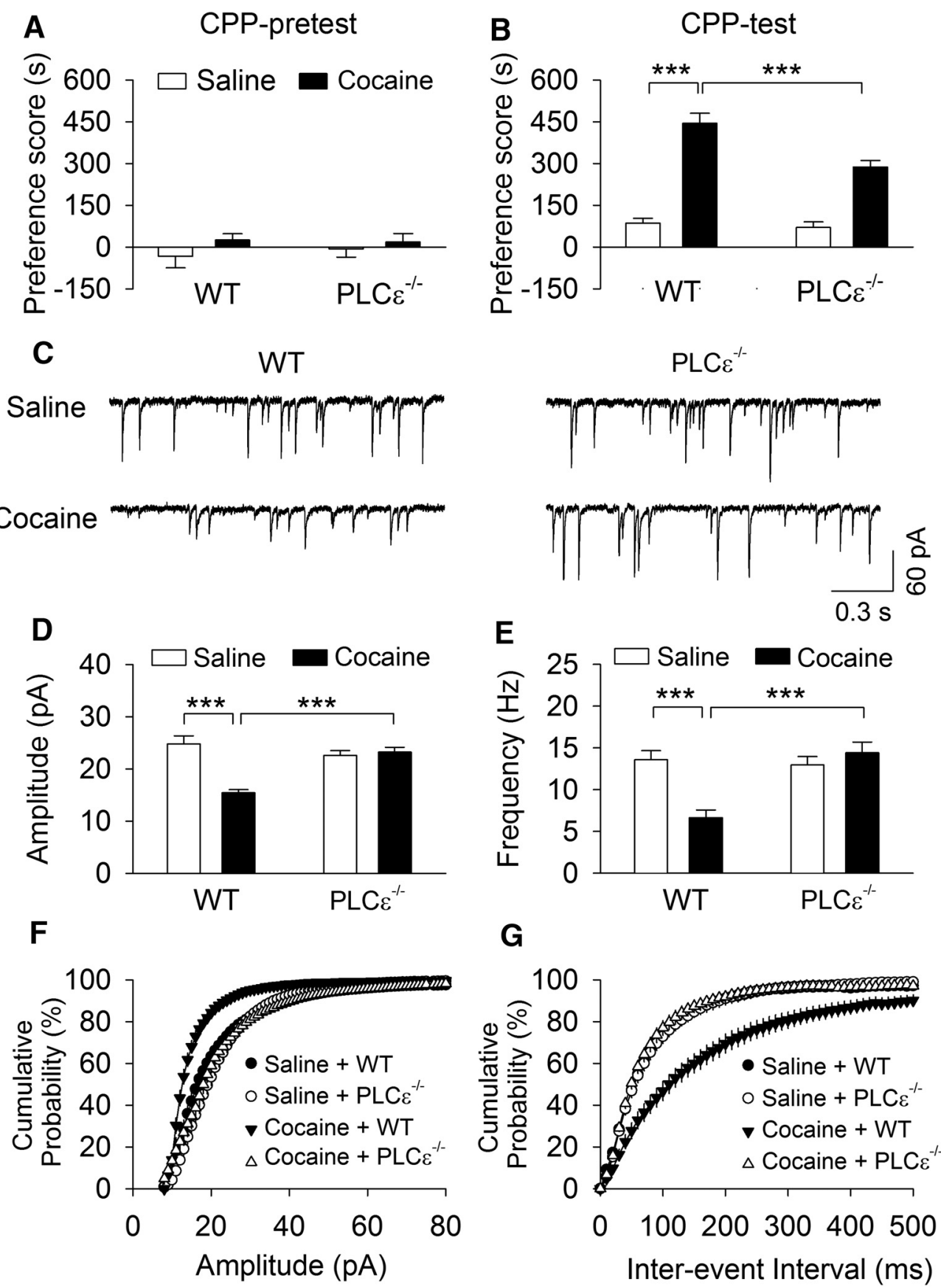

G

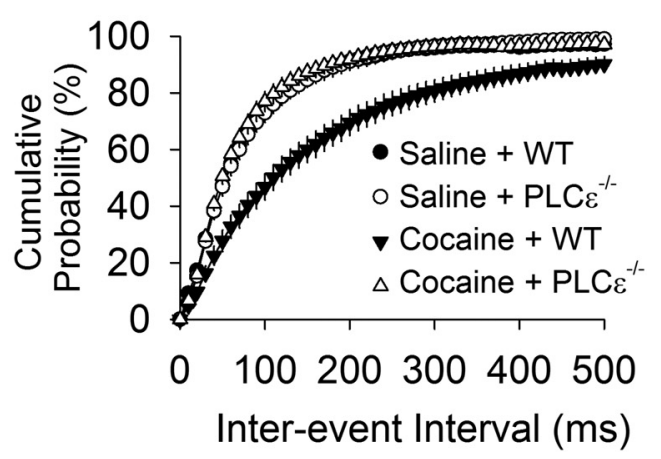

Figure 7. Cocaine conditioning-induced reduction of GABAergic inhibition was attenuated in $P L \varepsilon^{-/-}$mice. A, Wild-type (WT) and $P L C \varepsilon^{-/-}$mice exhibited no significant unconditioned preference (baseline bias) in each chamber during pretest $(n=8-10, p>0.05)$. B, Cocaine CPP was attenuated in $P L C \varepsilon^{-/-}$mice compared with that of WT mice $\left(n=9-10\right.$, $\left.{ }^{* * *} p<0.01\right)$. C, Representative sIPSCs recorded from VTA dopamine neurons in slices prepared from saline-conditioned or cocaine-conditioned WT or PLC $\varepsilon^{-/-}$mice. $\boldsymbol{D}, \boldsymbol{E}$, The averaged amplitude (D) and frequency $(\boldsymbol{E})$ of sIPSCs in VTA dopamine neurons in these four groups of mice. The mean amplitude and frequency of sIPSCs were significantly decreased in cocaine-conditioned WT mice $(n=$ $14-15,{ }^{* * *} p<0.001$ ), and this decrease was blocked in $P L C \varepsilon^{-/-}$mice (both $n=14$, $\left.{ }^{* * *} p<0.001\right) . F, G$, The cumulative probability plots indicated that cocaine conditioning led to shifts in the distribution of the amplitude $(\boldsymbol{F})$ and interevent intervals $(\boldsymbol{G})$ in WT mice. These shifts were blocked in $P L \varepsilon^{-/-}$mice $(n=12, p<0.01)$.

sIPSCs $(p<0.001$; Fig. $7 D)$ in wild-type mice; this decrease was blocked in $P L C \varepsilon^{-1-}$ mice $(p<0.001$; Fig. $7 D)$. The cumulative distribution for the amplitude of sIPSCs was shifted to the left (i.e., smaller value) in wild-type mice that received cocaine conditioning, and this shift was blocked in $P L C \varepsilon^{-/-}$mice (Fig. $7 F$ ).

Cocaine conditioning $\left(F_{(1,55)}=6.5, p=0.014\right)$ and genotype $\left(F_{(1,55)}=10.9, p=0.002\right)$ had significant effects on the mean frequency of sIPSCs, and there was a significant interaction between cocaine conditioning and genotype $\left(F_{(1,55)}=15.7, p<\right.$
0.001; Fig. 7C,E). Tukey's post hoc tests indicated that cocaine conditioning significantly decreased the frequency of sIPSCs $(p<0.001$; Fig. $7 E)$ in wild-type mice, and this decrease was blocked in $P L C \varepsilon^{-/-}$mice $(p<0.001$; Fig. $7 E)$. The cumulative distribution for interevent intervals of sIPSCs was shifted to the right (i.e., longer interval and less frequent) in wild-type mice that received cocaine conditioning, and this shift was blocked in $P L C \varepsilon^{-/-}$mice (Fig. $7 G$ ). Together, these results indicate that cocaine CPP led to the reduction of GABAergic inhibition to 
A

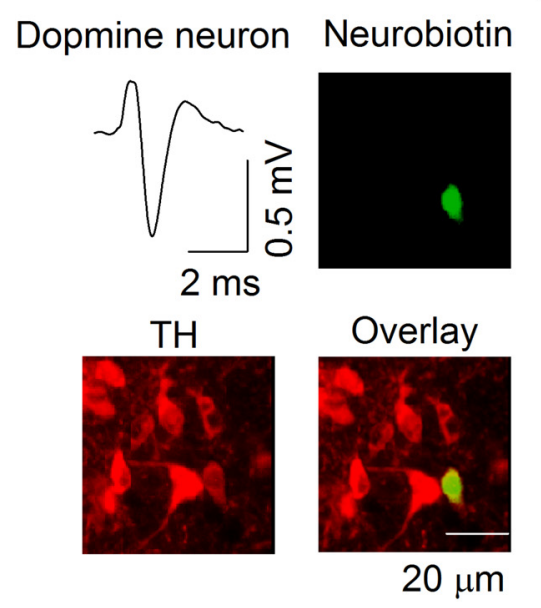

B
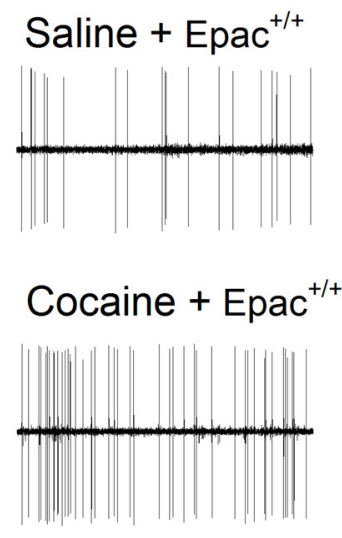

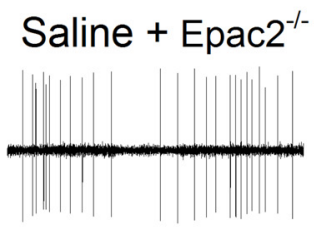

Cocaine $+\mathrm{Epac2}^{--}$

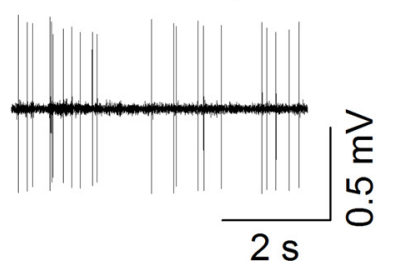

C

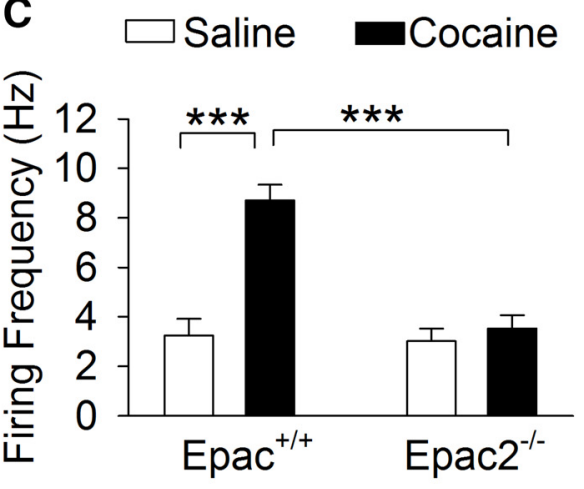

E

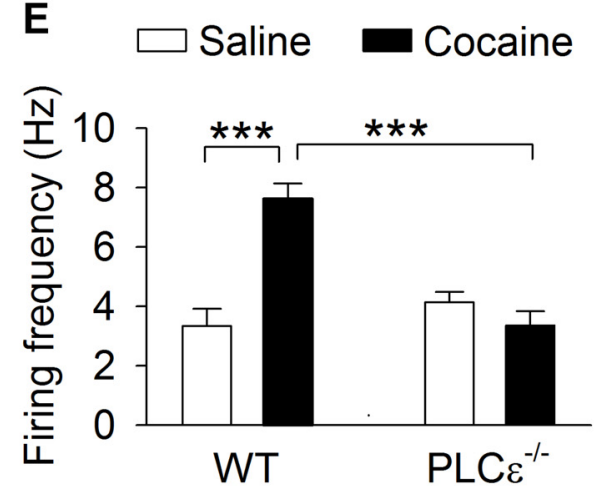

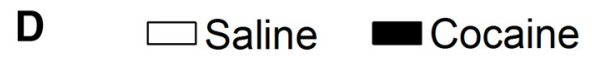
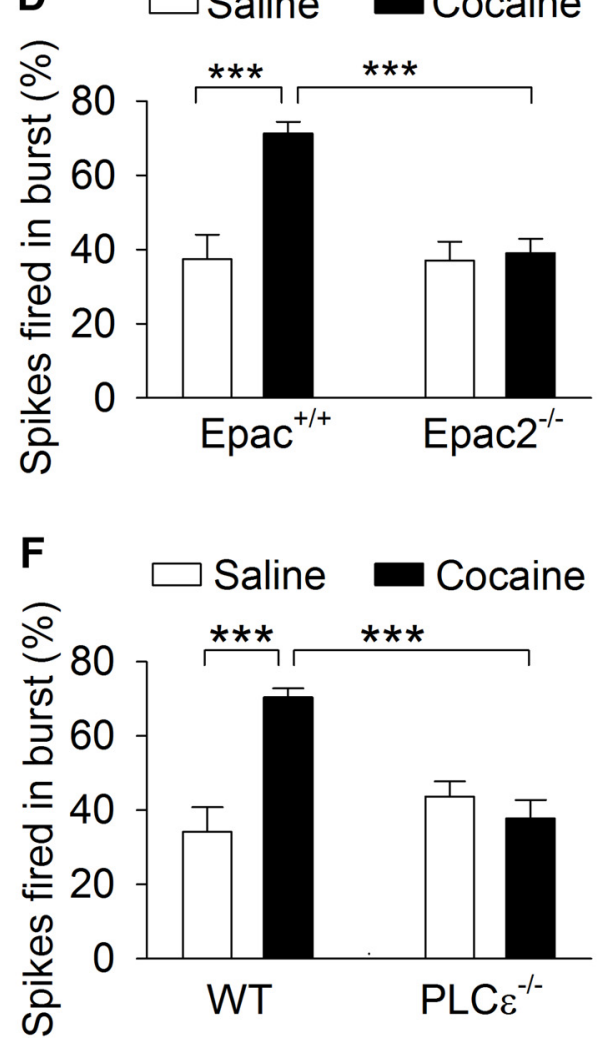

Figure 8. The Epac-PLC $\varepsilon$ pathway is required for cocaine conditioning-induced increase in action potential firing of VTA dopamine neurons in vivo. A, Dopamine neurons were identified by a broad triphasic extracellular action potential of a width of $>2 \mathrm{~ms}$ and juxtacellular labeling with neurobiotin. Post hoc immunostaining showed that the electrophysiologically identified dopamine neuron was colabeled with neurobiotin (green) and TH (red). $\boldsymbol{B}$, Examples of action potential firing recorded from saline-conditioned or cocaine-conditioned Epac ${ }^{+/+}$and Epac2 ${ }^{-/-}$mice. $\boldsymbol{C}, \boldsymbol{D}$, Cocaine conditioning led to increases in the frequency of action potential firing $(\boldsymbol{C})$ and the proportion of spikes that occurred in a burst (D) in Epac ${ }^{+/+}$mice $\left(\right.$both $\left.n=12-13,{ }^{* * *} p<0.001\right)$. These increases were blocked in Epac2 ${ }^{-1-}$ mice $\left(n=13-14,{ }^{* * *} p<0.001\right) . \boldsymbol{E}, \boldsymbol{F}$, Repeated cocaine exposure caused increases in the frequency of action potential firing $(\boldsymbol{E})$ and the proportion of spikes that occurred in a burst $\left(\boldsymbol{F}\right.$; both $\left.n=11-12,{ }^{* * *} p<0.001\right)$ in WT mice. These increases were blocked in $P L C \varepsilon^{-/-}$mice $\left(\right.$both $\left.n=12-15,{ }^{* * *} p<0.001\right)$.

VTA dopamine neurons in wild-type mice, and this reduction was blocked in $P L C \varepsilon^{-/-}$mice.

Cocaine CPP produced Epac2-PLCE-dependent increase in action potential firing of VTA dopamine neurons in vivo Cocaine-induced reduction of the amplitude and frequency sIPSCs in VTA dopamine neurons may cause disinhibition and therefore increase the excitability of these neurons. To test this, we made in vivo single-unit extracellular recordings from VTA dopamine neurons in saline-conditioned and cocaine-conditioned wild-type, Epac2 ${ }^{-1-}$, and $P L C \varepsilon^{-1-}$ mice shown in Figures 6 and 7 , respectively. One day after the CPP test, the mice were anesthetized with urethane and in vivo single-unit recordings were performed. Dopamine neurons were identified by a broad triphasic extracellular action potential with a width of $>2 \mathrm{~ms}$ and a relatively slow firing rate $(<10 \mathrm{~Hz}$; Ungless et al., 2004; Fig. $8 A, B)$. Dopamine neurons were validated postmortem via juxtacellular labeling with neurobiotin and $\mathrm{TH}$ immunostaining (Ungless et al., 2004; Chaudhury et al., 2013; Fig. 8A). In $\mathrm{Epac2}^{-/-}$mice, we found that cocaine place conditioning and 
genotype had significant effects on the frequency of action potential firing (cocaine: $F_{(1,51)}=21.1, p<0.001 ;$ Epac2 $^{-/-}: F_{(1,51)}=$ 26.0, $p<0.001$; cocaine $\times$ Epac $^{-1-}$ interaction $F_{(1,51)}=17.9$, $p<0.001$; Fig. $8 B, C$ ), and the percentage of spikes in bursts in VTA dopamine neurons (cocaine: $F_{(1,51)}=14.4, p<0.001$; Epac2 $^{-/-}: F_{(1,51)}=11.9, p=0.001$; cocaine $\times E_{\text {Epac2 }}{ }^{-/-}$interaction: $F_{(1,51)}=11.3, p=0.002$; Fig. $\left.8 B, D\right)$. Tukey's post hoc tests indicated that cocaine place conditioning significantly increased the frequency of action potential firing and the percentage of spikes in bursts in $E_{p a c}{ }^{+/+}$mice (both $p$ 's $<0.001$ ), but not in $E_{p a c 2}{ }^{-/-}$mice (both $p$ 's $>0.05$ ). There were no significant differences of the firing frequency and the percentage of spikes in bursts between $\mathrm{Epac}^{+/+}$and Epac2 $2^{-/-}$mice that received saline conditioning (both $p$ 's $>0.05$ ).

In $P L C \varepsilon^{-/-}$mice, cocaine place conditioning and genotype had significant effects on the frequency of action potential firing (cocaine: $F_{(1,50)}=14.4, p<0.001 ; P L C \varepsilon^{-/-}: F_{(1,50)}=14.1, p<$ 0.001 ; cocaine $\times P L C \varepsilon^{-/-}$interaction $F_{(1,50)}=29.9, p<0.001$; Fig. $8 E$ ), and the percentage of spikes in bursts in VTA dopamine neurons (cocaine: $F_{(1,50)}=11.1, p=0.001 ; P L C \varepsilon^{-/-}: F_{(1,50)}=$ $6.4, p=0.015$; cocaine $\times P L C \varepsilon^{-/-}$interaction: $F_{(1,50)}=21.4$, $p<0.001$; Fig. $8 F$ ). Tukey's post hoc tests indicated that cocaine place conditioning significantly increased the frequency of action potential firing and the percentage of spikes in bursts in wild-type mice (both $p$ 's $<0.001$ ), but not in $P L C \varepsilon^{-/-}$mice (both $p$ 's $>$ $0.05)$. There were no significant differences of the firing frequency and the percentage of spikes in bursts between wild-type and $P L C \varepsilon^{-/-}$mice that received saline conditioning (both $p$ 's $>$ $0.05)$. Thus, cocaine place conditioning caused an increase in the excitability of VTA dopamine neurons, and this increase was blocked in Epac2 and PLCe knock-out mice.

\section{Discussion}

The present study has shown that the selective Epac agonist 8-CPT enabled $\mathrm{CB}_{1}$ receptor-mediated DSI and I-LTD in VTA dopamine neurons in wild-type mice, and the effects of 8-CPT were blocked in Epac2-deficient and PLC $\varepsilon$-deficient mice. These results uncovered a novel mechanism for on-demand synthesis of retrograde signaling 2-AG by the Epac2-PLC $\varepsilon$ pathway. In addition, we provide evidence that Epac2-PLCe is required for the reduction of GABAergic inhibition to VTA dopamine neurons induced by cocaine place conditioning.

\section{Facilitation of DSI and I-LTD by 8-CPT}

Consistent with previous studies (Pan et al., 2008a), we found that depolarization of VTA dopamine neurons was not sufficient to induce DSI in VTA dopamine neurons, and repetitive synaptic stimulation at $10 \mathrm{~Hz}$ for $5 \mathrm{~min}$ was subthreshold for I-LTD induction. The present study showed that 8-CPT enabled DSI and I-LTD, and the effects of 8-CPT were blocked in Epac2 ${ }^{-/-}$mice, but not in $\mathrm{Epac1}^{-/-}$mice. Thus, 8-CPT facilitated DSI and I-LTD by activating Epac2. The lack of effects in $\mathrm{Epac1}^{-1-}$ mice may be explained by low expression of Epac1 in the brain (Kawasaki et al., 1998; de Rooij et al., 1998; Ostroveanu et al., 2010). Previous studies have shown that robust DSI was induced by depolarization alone in rat VTA dopamine neurons (Melis et al., 2009, 2013 b, 2014). In these studies, IPSCs were evoked by selectively stimulating rostromedial tegmental nucleus (RMTg) afferents, which highly express $\mathrm{CB}_{1}$ receptors (Melis et al., 2014). In support of this premise, the $\mathrm{CB}_{1}$ receptor agonist WIN55212-2 produced robust depression of IPSCs evoked by stimulating the RMTg and blocked RMTg-evoked suppression of VTA dopamine neuron firing (Melis et al., 2009; Lecca et al., 2012). In the present study, IPSCs were evoked by nonselectively stimulating inhibitory synaptic inputs, which may potentially account for the absence of DSI from depolarization alone in our study.

DSI and I-LTD are mediated by the activation of $\mathrm{CB}_{1}$ receptors by 2-AG, as they were blocked by pharmacological inhibition or genetic knock-out of DAGL (Chevaleyre and Castillo, 2003; Pan et al., 2009; Gao et al., 2010; Tanimura et al., 2010) and prolonged by monoacylglycerol lipase inhibitors (Pan et al., 2009; Patel et al., 2009; Straiker et al., 2009). Indeed, we found that 8-CPT-enabled DSI and I-LTD were abolished by a recently developed, highly selective, and potent DAGL inhibitor DO34 (Ogasawara et al., 2016), but not by the inactive analog DO53. Thus, an increase in 2-AG production is likely responsible for 8-CPT-induced facilitation of DSI and I-LTD. In support of this idea, we found that intracellular perfusion of a high concentration of 8-CPT $(300 \mu \mathrm{M})$ induced depression of IPSCs in $\mathrm{Epac}^{+/+}$ slices, and the 8-CPT-induced depression was blocked by DO34 and was absent in Epac2 $2^{-/-}$slices. These results provide evidence that 8 -CPT facilitated DSI and I-LTD by increasing 2-AG production.

The group-I mGluR agonist DHPG induces 2-AG-mediated retrograde synaptic depression (Maejima et al., 2001; Varma et al., 2001) and facilitates DSI (Varma et al., 2001; Edwards et al., 2006). The effects of DHPG are likely mediated by increasing 2-AG production. Group-I mGluRs are coupled to PLC $\beta$ (Hashimotodani et al., 2005), which cleaves $\mathrm{PIP}_{2}$ into $\mathrm{IP}_{3}$ and DAG, and the latter is subsequently converted into 2-AG by DAGL (Di Marzo et al., 1998; Piomelli, 2003). There are at least six isoforms of PLC (PLC $\beta, \operatorname{PLC} \gamma, \operatorname{PLC} \delta, \operatorname{PLC} \varepsilon, \operatorname{PLC} \zeta, \operatorname{PLC} \eta$; Rhee and Bae, 1997; Hwang et al., 2005), and among them, PLC $\beta$ is required for 2-AG synthesis induced by group-I mGluR activation and depolarization-induced $\mathrm{Ca}^{2+}$ influx (Hashimotodani et al., 2005). TrkB receptor agonists BDNF and DHF enhance DSI and I-LTD in VTA dopamine neurons (Zhong et al., 2015). Given that TrkB is coupled to PLC $\gamma$ (Reichardt, 2006), a role for PLC $\gamma$ in 2-AG synthesis has been speculated but has not been examined experimentally (Zhong et al., 2015). Epac activates PLC $\varepsilon$ via its direct effector, the small GTPase Rap (Schmidt et al., 2001; Oestreich et al., 2007). We tested the possibility that 8-CPT enabled DSI and I-LTD through activation of PLC $\varepsilon$ and found that the effects of 8 -CPT on DSI and I-LTD were absent in PLC $\varepsilon^{-/-}$ slices. The lack of effects of 8-CPT cannot be attributed to gross disruption of 2-AG production due to permanent loss of PLC $\varepsilon$ from early development, since the mGluR agonist DHPG and the TrkB agonist DHF enabled DSI in wild-type and $P L C \varepsilon^{-/-}$slices. These results suggest that activation of the Epac2-PLC $\varepsilon$ pathway induces synthesis of retrograde signaling 2-AG. Although all PLC isoforms are capable of producing DAG (Rhee and Bae, 1997; Hwang et al., 2005), 2-AG production via mGluRs and depolarization-induced $\mathrm{Ca}^{2+}$ influx was previously only linked to PLC $\beta$ (Hashimotodani et al., 2005). The present results provide evidence that PLC $\varepsilon$ is involved in synthesizing retrograde signaling 2-AG.

Regulation of cocaine-induced reduction of GABAergic inhibition by the Epac2-PLCe pathway

We have shown that repeated cocaine exposure in vivo reduces the strength of GABAergic inhibition to VTA dopamine neurons (Liu et al., 2005; Pan et al., 2008a), which primes excitatory synapses for LTP induction (Liu et al., 2005; Pan et al., 2011). Endocannabinoid-mediated I-LTD may constitute a mechanism for cocaine-induced reduction of GABAergic inhibition (Pan et al., 2008a). Having shown that 8-CPT enabled DSI and I-LTD via 
activating Epac2 and PLCe, we examined whether the EpacPLC $\varepsilon$ pathway is required for the reduction of GABAergic inhibition to VTA dopamine neurons induced by cocaine exposure in vivo. We have shown recently that cocaine $\mathrm{CPP}$ was impaired in $\mathrm{Epac2}^{-1-}$ mice but was not altered in $\mathrm{Epac1}^{-1-}$ mice (Liu et al., 2016). We examined whether cocaine CPP was accompanied by a change in GABAergic inhibition to VTA dopamine neurons. The results showed that cocaine place conditioning caused decreases in the frequency and amplitude of sIPSCs in wild-type mice, but not in Epac2 $2^{-1-}$ mice or in PLC $\varepsilon^{-/-}$mice. Thus, the Epac-PLC $\varepsilon$ pathway is required for the cocaine-induced reduction of GABAergic inhibition to VTA dopamine neurons, and the disruption of Epac signaling attenuates the behavioral reinforcement induced by cocaine. Although cocaine-induced decreases in amplitude and frequency of sIPSCs were blocked in the Epac2 $2^{-/-}$ mice, CPP was only attenuated in these mice. CPP is a complex behavior that is likely involved in multiple signaling pathways and multiple brain regions (Bardo and Bevins, 2000).

What might be the mechanism for the involvement of Epac$\mathrm{PLC} \varepsilon$ in cocaine-induced reduction of GABAergic inhibition? A common cocaine-induced neuroadaptation is an upregulation of cAMP signaling in the mesolimbic dopamine system (Nestler, 2001; Anderson and Pierce, 2005). Repeated cocaine exposure in vivo leads to reduction of $\mathrm{G} \alpha_{\mathrm{i} / \mathrm{o}}$-protein levels (Nestler et al., 1990; Striplin and Kalivas, 1992) and enhancement of adenylate cyclase activity and cAMP accumulation (Watts and Neve, 2005). Cocaine-induced upregulation of cAMP signaling may activate the Epac-PLC $\varepsilon$ pathway, leading to increased 2-AG production. The repeated activation of this signaling cascade may induce an I-LTD-like synaptic modulation via cAMP-induced Epac2 activation in VTA dopamine neurons, leading to 2-AG synthesis and a reduction in the strength of GABAergic inhibition to VTA dopamine neurons. By activating PLC $\varepsilon$, Epac links the cAMPadenylate cyclase pathway and the $\mathrm{DAG} / \mathrm{IP}_{3}$-PLC pathway and provides a novel mechanism for the crosstalk between these two common G-protein signaling pathways.

Epac2-PLCe is required for cocaine-induced increase in dopamine neuron excitability

Cocaine-induced reduction of GABAergic inhibition causes disinhibition of VTA dopamine neurons and increases their excitability (Liu et al., 2005; Bocklisch et al., 2013). We found that cocaine conditioning increased in vivo action potential firing in VTA dopamine neurons, and this increase was blocked in $\mathrm{Epac2}^{-1-}$ and $\mathrm{PLC} \varepsilon^{-/-}$mice. Thus, the Epac2-PLC $\varepsilon$ pathway is involved in the cocaine-induced increase in excitability in VTA dopamine neurons. We have shown that intraperitoneal injection of AM251 blocked the decreases in IPSCs in VTA dopamine neurons induced by repeated cocaine exposure in vivo (Pan et al., 2008a). It is thus likely that endocannabinoid signaling contributes to cocaine-induced reduction of GABAergic inhibition and the increase in action potential firing. Cocaine exposure in vivo in rats or mice led to increases in insertion of GluA2-lacking AMPARs (Bellone and Lüscher, 2006; Good and Lupica, 2010; Liu et al., 2016) and in AMPAR/NMDAR ratio (Ungless et al., 2001; Borgland et al., 2004; Liu et al., 2005; Bellone and Lüscher, 2006; Mameli et al., 2007; 2009; Argilli et al., 2008). We have shown that Epac2 is required for both effects of cocaine (Liu et al., 2016). Thus, it is likely that both the cocaine-induced increase in the strength of excitatory synapses and decrease in the strength of inhibitory synapses contribute to the increase in excitability and action potential firing in VTA dopamine neurons.
In summary, we have shown that 8-CPT facilitated DSI and I-LTD in VTA dopamine neurons, and these effects were mediated via the activation of the Epac-PLC $\varepsilon$ pathway. In addition, this signaling pathway is also involved in cocaine conditioninginduced reduction of GABAergic inhibition and an increase in dopamine neuron excitability. Together, our studies suggest that Epac-PLC $\varepsilon$ plays a critical role in mediating cocaine-induced long-term synaptic plasticity at both excitatory and inhibitory synapses.

\section{References}

Anderson SM, Pierce RC (2005) Cocaine-induced alterations in dopamine receptor signaling: implications for reinforcement and reinstatement. Pharmacol Ther 106:389-403. CrossRef Medline

Argilli E, Sibley DR, Malenka RC, England PM, Bonci A (2008) Mechanism and time course of cocaine-induced long-term potentiation in the ventral tegmental area. J Neurosci 28:9092-9100. CrossRef Medline

Bardo MT, Bevins RA (2000) Conditioned place preference: what does it add to our preclinical understanding of drug reward? Psychopharmacology 153:31-43. CrossRef Medline

Bellone C, Lüscher C (2006) Cocaine triggered AMPA receptor redistribution is reversed in vivo by mGluR-dependent long-term depression. Nat Neurosci 9:636-641. CrossRef Medline

Bishop MW, Chakraborty S, Matthews GA, Dougalis A, Wood NW, Festenstein R, Ungless MA (2010) Hyperexcitable substantia nigra dopamine neurons in PINK1- and HtrA2/Omi-deficient mice. J Neurophysiol 104: 3009-3020. CrossRef Medline

Bocklisch C, Pascoli V, Wong JC, House DR, Yvon C, de Roo M, Tan KR, Lüscher C (2013) Cocaine disinhibits dopamine neurons by potentiation of GABA transmission in the ventral tegmental area. Science 341: 1521-1525. CrossRef Medline

Borgland SL, Malenka RC, Bonci A (2004) Acute and chronic cocaineinduced potentiation of synaptic strength in the ventral tegmental area: electrophysiological and behavioral correlates in individual rats. J Neurosci 24:7482-7490. CrossRef Medline

Brischoux F, Chakraborty S, Brierley DI, Ungless MA (2009) Phasic excitation of dopamine neurons in ventral VTA by noxious stimuli. Proc Natl Acad Sci U S A 106:4894-4899. CrossRef Medline

Chaudhury D, Walsh JJ, Friedman AK, Juarez B, Ku SM, Koo JW, Ferguson D, Tsai HC, Pomeranz L, Christoffel DJ, Nectow AR, Ekstrand M, Domingos A, Mazei-Robison MS, Mouzon E, Lobo MK, Neve RL, Friedman JM, Russo SJ, Deisseroth K, et al. (2013) Rapid regulation of depressionrelated behaviours by control of midbrain dopamine neurons. Nature 493:532-536. CrossRef Medline

Chen L, Lodge DJ (2013) The lateral mesopontine tegmentum regulates both tonic and phasic activity of VTA dopamine neurons. J Neurophysiol 110:2287-2294. CrossRef Medline

Chen Y, Liu X, Vickstrom CR, Liu MJ, Zhao L, Viader A, Cravatt BF, Liu QS (2016) Neuronal and astrocytic monoacylglycerol lipase limit the spread of endocannabinoid signaling in the cerebellum. eNeuro 3:pii: ENEURO.0048-16.2016. CrossRef Medline

Cheng X, Ji Z, Tsalkova T, Mei F (2008) Epac and PKA: a tale of two intracellular cAMP receptors. Acta Biochim Biophys Sin (Shanghai) 40:651662. CrossRef Medline

Chevaleyre V, Castillo PE (2003) Heterosynaptic LTD of hippocampal GABAergic synapses: a novel role of endocannabinoids in regulating excitability. Neuron 38:461-472. CrossRef Medline

Chevaleyre V, Castillo PE (2004) Endocannabinoid-mediated metaplasticity in the hippocampus. Neuron 43:871-881. CrossRef Medline

Chevaleyre V, Heifets BD, Kaeser PS, Südhof TC, Purpura DP,Castillo PE (2007) Endocannabinoid-mediated long-term plasticity requires cAMP/ PKA signaling and RIM1alpha. Neuron 54:801-812. CrossRef Medline

Chieng B, Azriel Y, Mohammadi S, Christie MJ (2011) Distinct cellular properties of identified dopaminergic and GABAergic neurons in the mouse ventral tegmental area. J Physiol 589:3775-3787. CrossRef Medline

de Rooij J, Zwartkruis FJ, Verheijen MH, Cool RH, Nijman SM, Wittinghofer A, Bos JL (1998) Epac is a Rapl guanine-nucleotide-exchange factor directly activated by cyclic AMP. Nature 396:474-477. CrossRef Medline

Di Marzo V, Melck D, Bisogno T, De Petrocellis L (1998) Endocannabinoids: endogenous cannabinoid receptor ligands with neuromodulatory action. Trends Neurosci 21:521-528. CrossRef Medline 
Edwards DA, Kim J, Alger BE (2006) Multiple mechanisms of endocannabinoid response initiation in hippocampus. J Neurophysiol 95:67-75. Medline

Enserink JM, Christensen AE, de Rooij J, van Triest M, Schwede F, Genieser HG, Døskeland SO, Blank JL, Bos JL (2002) A novel Epac-specific cAMP analogue demonstrates independent regulation of Rap1 and ERK. Nat Cell Biol 4:901-906. CrossRef Medline

Fernandes HB, Riordan S, Nomura T, Remmers CL, Kraniotis S, Marshall JJ, Kukreja L, Vassar R, Contractor A (2015) Epac2 mediates cAMPdependent potentiation of neurotransmission in the hippocampus. J Neurosci 35:6544-6553. CrossRef Medline

Gao Y, Vasilyev DV, Goncalves MB, Howell FV, Hobbs C, Reisenberg M, Shen R, Zhang MY, Strassle BW, Lu P, Mark L, Piesla MJ, Deng K, Kouranova EV, Ring RH, Whiteside GT, Bates B, Walsh FS, Williams G, Pangalos MN, et al. (2010) Loss of retrograde endocannabinoid signaling and reduced adult neurogenesis in diacylglycerol lipase knock-out mice. J Neurosci 30:2017-2024. CrossRef Medline

Gekel I, Neher E (2008) Application of an Epac activator enhances neurotransmitter release at excitatory central synapses. J Neurosci 28:79918002. CrossRef Medline

Gelinas JN, Banko JL, Peters MM, Klann E, Weeber EJ, Nguyen PV (2008) Activation of exchange protein activated by cyclic-AMP enhances longlasting synaptic potentiation in the hippocampus. Learn Mem 15:403411. CrossRef Medline

Gerdeman GL, Ronesi J, Lovinger DM (2002) Postsynaptic endocannabinoid release is critical to long-term depression in the striatum. Nat Neurosci 5:446-451. Medline

Gloerich M, Bos JL (2010) Epac: defining a new mechanism for cAMP action. Annu Rev Pharmacol Toxicol 50:355-375. CrossRef Medline

Good CH, Lupica CR (2010) Afferent-specific AMPA receptor subunit composition and regulation of synaptic plasticity in midbrain dopamine neurons by abused drugs. J Neurosci 30:7900-7909. CrossRef Medline

Grace AA, Bunney BS (1984) The control of firing pattern in nigral dopamine neurons: burst firing. J Neurosci 4:2877-2890. Medline

Hashimotodani Y, Ohno-Shosaku T, Tsubokawa H, Ogata H, Emoto K, Maejima T, Araishi K, Shin HS, Kano M (2005) Phospholipase Cbeta serves as a coincidence detector through its $\mathrm{Ca} 2+$ dependency for triggering retrograde endocannabinoid signal. Neuron 45:257-268. CrossRef Medline

Hewer RC, Sala-Newby GB, Wu YJ, Newby AC, Bond M (2011) PKA and Epac synergistically inhibit smooth muscle cell proliferation. J Mol Cell Cardiol 50:87-98. CrossRef Medline

Hoover HS, Blankman JL, Niessen S, Cravatt BF (2008) Selectivity of inhibitors of endocannabinoid biosynthesis evaluated by activity-based protein profiling. Bioorg Med Chem Lett 18:5838-5841. CrossRef Medline

Hwang JI, Oh YS, Shin KJ, Kim H, Ryu SH, Suh PG (2005) Molecular cloning and characterization of a novel phospholipase C, PLC-eta. Biochem J 389:181-186. CrossRef Medline

Johnson SW, North RA (1992) Two types of neurone in the rat ventral tegmental area and their synaptic inputs. J Physiol 450:455-468. CrossRef Medline

Jones S, Kauer JA (1999) Amphetamine depresses excitatory synaptic transmission via serotonin receptors in the ventral tegmental area. J Neurosci 19:9780-9787. Medline

Kawasaki H, Springett GM, Mochizuki N, Toki S, Nakaya M, Matsuda M, Housman DE, Graybiel AM (1998) A family of cAMP-binding proteins that directly activate Rap1. Science 282:2275-2279. CrossRef Medline

Kreitzer AC, Regehr WG (2001) Retrograde inhibition of presynaptic calcium influx by endogenous cannabinoids at excitatory synapses onto Purkinje cells. Neuron 29:717-727. CrossRef Medline

Lapointe JY, Szabo G (1987) A novel holder allowing internal perfusion of patch-clamp pipettes. Pflugers Arch 410:212-216. CrossRef Medline

Lecca S, Melis M, Luchicchi A, Muntoni AL, Pistis M (2012) Inhibitory inputs from rostromedial tegmental neurons regulate spontaneous activity of midbrain dopamine cells and their responses to drugs of abuse. Neuropsychopharmacology 37:1164-1176. CrossRef Medline

Liu QS, Pu L, Poo MM (2005) Repeated cocaine exposure in vivo facilitates LTP induction in midbrain dopamine neurons. Nature 437:1027-1031. CrossRef Medline

Liu X, Chen Y, Tong J, Reynolds AM, Proudfoot SC, Qi J, Penzes P, Lu Y, Liu QS (2016) Epac signaling is required for cocaine-induced change in AMPA receptor subunit composition in the ventral tegmental area. J Neurosci 36:4802-4815. CrossRef Medline
Maathuis JM, Taylor AR, Assmann SM, Sanders D (1997) Seal-promoting solutions and pipette perfusion for patch clamping plant cells. Plant J 11:891-896. CrossRef Medline

Maejima T, Hashimoto K, Yoshida T, Aiba A, Kano M (2001) Presynaptic inhibition caused by retrograde signal from metabotropic glutamate to cannabinoid receptors. Neuron 31:463-475. CrossRef Medline

Mameli M, Balland B, Luján R, LüscherC (2007) Rapid synthesis and synaptic insertion of GluR2 for mGluR-LTD in the ventral tegmental area. Science 317:530-533. CrossRef Medline

Mameli M, Halbout B, Creton C, Engblom D, Parkitna JR, Spanagel R, Lüscher C (2009) Cocaine-evoked synaptic plasticity: persistence in the VTA triggers adaptations in the NAc. Nat Neurosci 12:1036-1041. CrossRef Medline

Melis M, Pillolla G, Luchicchi A, Muntoni AL, Yasar S, Goldberg SR, Pistis M (2008) Endogenous fatty acid ethanolamides suppress nicotine-induced activation of mesolimbic dopamine neurons through nuclear receptors. J Neurosci 28:13985-13994. CrossRef Medline

Melis M, Pillolla G, Perra S, Colombo G, Muntoni AL, Pistis M (2009) Electrophysiological properties of dopamine neurons in the ventral tegmental area of Sardinian alcohol-preferring rats. Psychopharmacology 201:471481. CrossRef Medline

Melis M, Scheggi S, Carta G, Madeddu C, Lecca S, Luchicchi A, Cadeddu F, Frau R, Fattore L, Fadda P, Ennas MG, Castelli MP, Fratta W, Schilstrom B, Banni S, De Montis MG, Pistis M (2013a) PPARalpha regulates cholinergic-driven activity of midbrain dopamine neurons via a novel mechanism involving alpha7 nicotinic acetylcholine receptors. J Neurosci 33:6203-6211. CrossRef Medline

Melis M, De Felice M, Lecca S, Fattore L, Pistis M (2013b) Sex-specific tonic 2 -arachidonoylglycerol signaling at inhibitory inputs onto dopamine neurons of Lister Hooded rats. Front Integr Neurosci 7:93. CrossRef Medline

Melis M, Sagheddu C, De Felice M, Casti A, Madeddu C, Spiga S, Muntoni AL, Mackie K, Marsicano G, Colombo G, Castelli MP, Pistis M (2014) Enhanced endocannabinoid-mediated modulation of rostromedial tegmental nucleus drive onto dopamine neurons in Sardinian alcoholpreferring rats. J Neurosci 34:12716-12724. CrossRef Medline

Nestler EJ (2001) Molecular neurobiology of addiction. Am J Addict 10: 201-217. CrossRef Medline

Nestler EJ, Terwilliger RZ, Walker JR, Sevarino KA, Duman RS (1990) Chronic cocaine treatment decreases levels of the G protein subunits Gi alpha and Go alpha in discrete regions of rat brain. J Neurochem 55:1079_ 1082. CrossRef Medline

Oestreich EA, Wang H, Malik S, Kaproth-Joslin KA, Blaxall BC, Kelley GG, Dirksen RT, Smrcka AV (2007) Epac-mediated activation of phospholipase $\mathrm{C}$ (epsilon) plays a critical role in beta-adrenergic receptordependent enhancement of $\mathrm{Ca} 2+$ mobilization in cardiac myocytes. J Biol Chem 282:5488-5495. CrossRef Medline

Ogasawara D, Deng H, Viader A, Baggelaar MP, Breman A, den Dulk H, van den Nieuwendijk AM, Soethoudt M, van der Wel T, Zhou J, Overkleeft HS, Sanchez-Alavez M, Mori S, Mo S, Nguyen W, Conti B, Liu X, Chen Y, Liu QS, Cravatt BF, et al. (2016) Rapid and profound rewiring of brain lipid signaling networks by acute diacylglycerol lipase inhibition. Proc Natl Acad Sci U S A 113:26-33. CrossRef Medline

Ohno-Shosaku T, Maejima T, Kano M (2001) Endogenous cannabinoids mediate retrograde signals from depolarized postsynaptic neurons to presynaptic terminals. Neuron 29:729-738. CrossRef Medline

Ostroveanu A, van der Zee EA, Eisel UL, Schmidt M, Nijholt IM (2010) Exchange protein activated by cyclic AMP 2 (Epac2) plays a specific and time-limited role in memory retrieval. Hippocampus 20:1018-1026. CrossRef Medline

Ouyang M, Zhang L, Zhu JJ, Schwede F, Thomas SA (2008) Epac signaling is required for hippocampus-dependent memory retrieval. Proc Natl Acad Sci U S A 105:11993-11997. CrossRef Medline

Pan B, Hillard CJ, Liu QS (2008a) Endocannabinoid signaling mediates cocaine-induced inhibitory synaptic plasticity in midbrain dopamine neurons. J Neurosci 28:1385-1397. CrossRef Medline

Pan B, Hillard CJ, Liu QS (2008b) D2 dopamine receptor activation facilitates endocannabinoid-mediated long-term synaptic depression of GABAergic synaptic transmission in midbrain dopamine neurons via cAMP-protein kinase A signaling. J Neurosci 28:14018-14030. CrossRef Medline

Pan B, Wang W, Long JZ, Sun D, Hillard CJ, Cravatt BF, Liu QS (2009) Blockade of 
2-arachidonoylglycerol hydrolysis by selective monoacylglycerol lipase inhibitor 4-nitrophenyl 4-(dibenzo[d] [1,3] dioxol-5-yl(hydroxy)methyl)piperidine-1carboxylate (JZL184) Enhances retrograde endocannabinoid signaling. J Pharmacol Exp Ther 331:591-597. CrossRef Medline

Pan B, Zhong P, Sun D, Liu QS (2011) Extracellular signal-regulated kinase signaling in the ventral tegmental area mediates cocaine-induced synaptic plasticity and rewarding effects. J Neurosci 31:11244-11255. CrossRef Medline

Patel S, Kingsley PJ, Mackie K, Marnett LJ, Winder DG (2009) Repeated homotypic stress elevates 2-arachidonoylglycerol levels and enhances short-term endocannabinoid signaling at inhibitory synapses in basolateral amygdala. Neuropsychopharmacology 34:2699-2709. CrossRef Medline

Pinault D (1996) A novel single-cell staining procedure performed in vivo under electrophysiological control: morpho-functional features of juxtacellularly labeled thalamic cells and other central neurons with biocytin or Neurobiotin. J Neurosci Methods 65:113-136. CrossRef Medline

Piomelli D (2003) The molecular logic of endocannabinoid signalling. Nat Rev 4:873-884. CrossRef Medline

Reichardt LF (2006) Neurotrophin-regulated signalling pathways. Philos Trans R Soc Lond B Biol Sci 361:1545-1564. CrossRef Medline

Rhee SG, Bae YS (1997) Regulation of phosphoinositide-specific phospholipase C isozymes. J Biol Chem 272:15045-15048. CrossRef Medline

Robbe D, Kopf M, Remaury A, Bockaert J, Manzoni OJ (2002) Endogenous cannabinoids mediate long-term synaptic depression in the nucleus accumbens. Proc Natl Acad Sci U S A 99:8384-8388. CrossRef Medline

Safo PK, Regehr WG (2005) Endocannabinoids control the induction of cerebellar LTD. Neuron 48:647-659. CrossRef Medline

Schiemann J, Schlaudraff F, Klose V, Bingmer M, Seino S, Magill PJ, Zaghloul KA, Schneider G, Liss B, Roeper J (2012) K-ATP channels in dopamine substantia nigra neurons control bursting and novelty-induced exploration. Nat Neurosci 15:1272-1280. CrossRef Medline

Schmidt M, Evellin S, Weernink PA, von Dorp F, Rehmann H, Lomasney JW, Jakobs KH (2001) A new phospholipase-C-calcium signalling pathway mediated by cyclic AMP and a Rap GTPase. Nat Cell Biol 3:1020-1024. CrossRef Medline

Schmidt M, Dekker FJ, Maarsingh H (2013) Exchange protein directly activated by cAMP (epac): a multidomain cAMP mediator in the regulation of diverse biological functions. Pharmacol Rev 65:670-709. CrossRef Medline

Smrcka AV, Brown JH, Holz GG (2012) Role of phospholipase C $\varepsilon$ in physiological phosphoinositide signaling networks. Cell Signal 24:1333-1343. CrossRef Medline

Srivastava DP, Jones KA, Woolfrey KM, Burgdorf J, Russell TA, Kalmbach A, Lee H, Yang C, Bradberry MM, Wokosin D, Moskal JR, Casanova MF, Waters J, Penzes P (2012) Social, communication, and cortical structural impairments in Epac2-deficient mice. J Neurosci 32:11864-11878. CrossRef Medline

Ster J, de Bock F, Bertaso F, Abitbol K, Daniel H, Bockaert J, Fagni L (2009) Epac mediates PACAP-dependent long-term depression in the hippocampus. J Physiol 587:101-113. CrossRef Medline

Straiker A, Hu SS, Long JZ, Arnold A, Wager-Miller J, Cravatt BF, Mackie K (2009) Monoacylglycerol lipase limits the duration of endocannabinoidmediated depolarization-induced suppression of excitation in autaptic hippocampal neurons. Mol Pharmacol 76:1220-1227. CrossRef Medline

Striplin CD, Kalivas PW (1992) Correlation between behavioral sensitization to cocaine and G protein ADP-ribosylation in the ventral tegmental area. Brain Res 579:181-186. CrossRef Medline

Tang JM, Wang J, Eisenberg RS (1992) Perfusing patch pipettes. Methods Enzymol 207:176-181. CrossRef Medline

Tanimura A, Yamazaki M, Hashimotodani Y, Uchigashima M, Kawata S, Abe M, Kita Y, Hashimoto K, Shimizu T, Watanabe M, Sakimura K, Kano M
(2010) The endocannabinoid 2-arachidonoylglycerol produced by diacylglycerol lipase alpha mediates retrograde suppression of synaptic transmission. Neuron 65:320-327. CrossRef Medline

Ungless MA, Whistler JL, Malenka RC, Bonci A (2001) Single cocaine exposure in vivo induces long-term potentiation in dopamine neurons. Nature 411:583-587. CrossRef Medline

Ungless MA, Magill PJ, Bolam JP (2004) Uniform inhibition of dopamine neurons in the ventral tegmental area by aversive stimuli. Science 303 : 2040-2042. CrossRef Medline

Varma N, Carlson GC, Ledent C, Alger BE (2001) Metabotropic glutamate receptors drive the endocannabinoid system in hippocampus. J Neurosci 21:RC188. Medline

Vialou V, Feng J, Robison AJ, Ku SM, Ferguson D, Scobie KN, Mazei-Robison MS, Mouzon E, Nestler EJ (2012) Serum response factor and cAMP response element binding protein are both required for cocaine induction of $\Delta$ FosB. J Neurosci 32:7577-7584. CrossRef Medline

Walker EM, Bispham JR, Hill SJ (1998) Nonselective effects of the putative phospholipase C inhibitor, U73122, on adenosine A1 receptor-mediated signal transduction events in Chinese hamster ovary cells. Biochem Pharmacol 56:1455-1462. CrossRef Medline

Wang H, Oestreich EA, Maekawa N, Bullard TA, Vikstrom KL, Dirksen RT, Kelley GG, Blaxall BC, Smrcka AV (2005) Phospholipase C epsilon modulates beta-adrenergic receptor-dependent cardiac contraction and inhibits cardiac hypertrophy. Circ Res 97:1305-1313. CrossRef Medline

Wang W, Sun D, Pan B, Roberts CJ, Sun X, Hillard CJ, Liu QS (2010) Deficiency in endocannabinoid signaling in the nucleus accumbens induced by chronic unpredictable stress. Neuropsychopharmacology 35:22492261. CrossRef Medline

Watts VJ, Neve KA (2005) Sensitization of adenylate cyclase by Galpha i/ocoupled receptors. Pharmacol Ther 106:405-421. CrossRef Medline

Wilson RI, Nicoll RA (2001) Endogenous cannabinoids mediate retrograde signalling at hippocampal synapses. Nature 410:588-592. CrossRef Medline

Woolfrey KM, Srivastava DP, Photowala H, Yamashita M, Barbolina MV, Cahill ME, Xie Z, Jones KA, Quilliam LA, Prakriya M, Penzes P (2009) Epac2 induces synapse remodeling and depression and its disease-associated forms alter spines. Nat Neurosci 12:1275-1284. CrossRef Medline

Wu D, Tadano M, Edamatsu H, Masago-Toda M, Yamawaki-Kataoka Y, Terashima T, Mizoguchi A, Minami Y, Satoh T, Kataoka T (2003) Neuronal lineage-specific induction of phospholipase Cepsilon expression in the developing mouse brain. Eur J Neurosci 17:1571-1580. CrossRef Medline

Yang Y, ShuX, Liu D, Shang Y, Wu Y, Pei L, Xu X, Tian Q, Zhang J, Qian K, Wang YX, Petralia RS, TuW, ZhuLQ, Wang JZ, LuY (2012) EPACnull mutation impairs learning and social interactions via aberrant regulation of miR-124 and Zif268 translation. Neuron 73:774-788. CrossRef Medline

Yu F, Zhong P, Liu X, Sun D, Gao HQ, Liu QS (2013) Metabotropic glutamate receptor I (mGluR1) antagonism impairs cocaine-induced conditioned place preference via inhibition of protein synthesis. Neuropsychopharmacology 38:1308-1321. CrossRef Medline

Zhao K, Wen R, Wang X, Pei L, Yang Y, Shang Y, Bazan N, Zhu LQ, Tian Q, Lu Y (2013) EPAC inhibition of SUR1 receptor increases glutamate release and seizure vulnerability. J Neurosci 33:8861-8865. CrossRef Medline

Zhong P, Wang W, Yu F, Nazari M, Liu X, Liu QS (2012) Phosphodiesterase 4 inhibition impairs cocaine-induced inhibitory synaptic plasticity and conditioned place preference. Neuropsychopharmacology 37:2377-2387. CrossRef Medline

Zhong P, Liu Y, Hu Y, Wang T, Zhao YP, Liu QS (2015) BDNF interacts with endocannabinoids to regulate cocaine-induced synaptic plasticity in mouse midbrain dopamine neurons. J Neurosci 35:4469-4481. CrossRef Medline 